\title{
Astronomical calibration of late middle Eocene radiolarian bioevents from ODP Site 1260 (equatorial Atlantic, Leg 207) and refinement of the global tropical radiolarian biozonation
}

\author{
Mathias Meunier and Taniel Danelian \\ Univ. Lille, CNRS, UMR 8198 - Evo-Eco-Paleo, 59000 Lille, France \\ Correspondence: Mathias Meunier (mathias.meunier@univ-lille.fr)
}

Received: 1 October 2021 - Revised: 26 November 2021 - Accepted: 29 November 2021 - Published: 7 February 2022

\begin{abstract}
The middle Eocene sedimentary sequence drilled at Ocean Drilling Program Site 1260 (Leg 207), Demerara Rise, western equatorial Atlantic, yielded a rich and diverse radiolarian fauna. The exceptionally expanded and complete sedimentary record of this site, as well as the existence of an orbital chronological framework, allowed us to study a number of radiolarian bioevents with a very fine temporal resolution. We compiled a well-resolved succession of 71 radiolarian bioevents (first occurrences, last occurrences, and evolutionary transitions) and provided calibrations to the geomagnetic polarity timescale and astronomical timescale. Comparison of the radiolarian successions at ODP Site 1260A with the northwestern Atlantic IODP Site U1403 and the IODP Sites U1331, U1332, and 1333, situated in eastern equatorial Pacific, allowed the demonstration of the synchroneity of primary radiolarian bioevents that underpin the middle Eocene zonal scheme. Several secondary bioevents were also found to be synchronous between the two oceans and were therefore used to define seven new subzones for the low-latitudinal middle Eocene sequences: Siphocampe ? amygdala interval subzone (RP13a), Coccolarnacium periphaenoides interval subzone (RP13b), Artostrobus quadriporus interval subzone (RP14a), Sethochytris triconiscus interval subzone (RP14b), Podocyrtis (Podocyrtopsis) apeza interval subzone (RP14c), Artobotrys biaurita interval subzone (RP15a), and Thyrsocyrtis (Pentalocorys) krooni interval subzone (RP15b). This refined radiolarian biozonation has significantly improved stratigraphic resolution and age control for the late middle Eocene interval (an average of two subzones per 1.5 million years). A substantial diachronism was also found in 20 secondary radiolarian bioevents between the two oceans. The majority of radiolarian species appear to have evolved first in the equatorial Atlantic Ocean and subsequently in the equatorial Pacific. However, the reasons for this pattern of diachroneity currently remain uncertain and would require a greater sampling coverage to be elucidated.
\end{abstract}

\section{Introduction}

Accurate chronostratigraphic frameworks are essential to decipher past processes and events of the Earth system, as well as the complex history of life on Earth. Amongst the biostratigraphically important Cenozoic marine microfossils, polycystine radiolaria offer major advantages for dating and correlating marine sediments because they are commonly preserved in the fossil record, they are globally distributed, and they experienced high evolutionary rates (De
Wever et al., 2001). They are particularly useful in oceanic basins where carbonate fossils are absent or poorly preserved (Lazarus, 2005). Due to old misconceptions about their evolution, radiolaria have long been neglected as they were considered to be long-ranging species of no biostratigraphic value. Riedel (1957) was the first to emphasize the value of Cenozoic radiolaria for biostratigraphy based on the examination of deep-sea cores collected during the Swedish Deep-Sea Expedition. The subsequent advent of scientific ocean drilling campaigns enhanced deep-sea sediment recov- 
ery and allowed extensive studies of radiolarian assemblages, which led to the establishment of the first tropical radiolarian biozonation for the Cenozoic (Riedel and Sanfilippo, 1970, 1971, 1978; Foreman, 1973; Sanfilippo and Riedel, 1973; Nigrini, 1974; Sanfilippo et al., 1985). Paleocene zones and subzones were subsequently added by Nishimura (1987, 1992) and Hollis (1993) based on material from higher latitudes. Sanfilippo and Nigrini (1998) revised the tropical biozonation and introduced an alphanumerical code for the Cenozoic (RP1-RP22 for the Paleogene) to facilitate correlation with other microfossil groups.

Radiolarian bioevents that define the Paleogene zones were finally calibrated to the geomagnetic polarity timescale (Kamikuri et al., 2012; Souza et al., 2017, 2021; Hollis et al., 2020). Absolute ages were provided by Kamikuri et al. (2012) for 226 early Eocene to late Oligocene radiolarian bioevents recorded in the equatorial Pacific Ocean by using age-depth models based on magnetostratigraphy. For their part, Hollis et al. (2020) provided absolute ages for 99 middle Paleocene to middle Eocene radiolarian bioevents by using age-depth models based on magnetobiochronology. The recent development of an orbitally calibrated stratigraphy for the Paleogene (Westerhold et al., 2012, 2014, 2015; Westerhold and Röhl, 2013; Boulila et al., 2018) opens new prospects for precise calibration of radiolarian bioevents, especially for the equatorial Atlantic, which remains less well documented and calibrated than the equatorial Pacific.

Here, we present a detailed biostratigraphic analysis of the middle Eocene radiolarian record of the Ocean Drilling Program (ODP) Site 1260, drilled on Demerara Rise (western equatorial Atlantic Ocean). This site provided a remarkably complete and continuous middle Eocene sedimentary sequence, which contains an abundant record of both siliceous and carbonate microfossils. A very well-defined framework in terms of both magnetostratigraphy and cyclostratigraphy is now available for this site (Westerhold and Röhl, 2013). Thus, the main objective of this study was to refine absolute ages of middle Eocene radiolarian bioevents through high-resolution faunal analysis of ODP Site 1260 and direct correlation with the geomagnetic polarity and astronomical timescales. We documented the stratigraphic distribution of radiolarian species at this site, including some species described in very early studies (i.e., Ehrenberg, 1874) and rarely reported since. Absolute ages of radiolarian bioevents derived from ODP Site 1260 were subsequently compared to previous biostratigraphic studies carried out at three lowlatitudinal sites in the Pacific (Kamikuri et al., 2012) and one midlatitudinal site in the Atlantic (Hollis et al., 2020) to assess the degree of synchroneity of radiolarian bioevents between the equatorial Atlantic and Pacific oceans, as well as between the low and middle latitudes of the Atlantic Ocean.

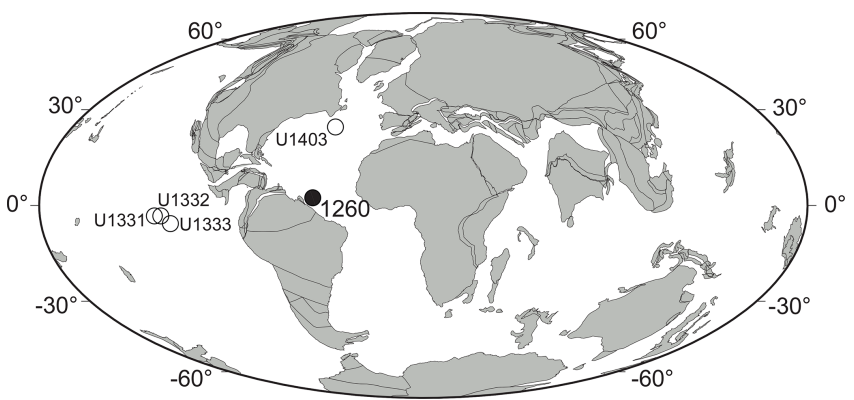

Figure 1. Middle Eocene (ca. $40 \mathrm{Ma}$ ) paleogeographic map showing the location of Demerara Rise (ODP Site 1260, Leg 207) (solid circle) and the four equatorial Pacific and North Atlantic IODP sites used for comparison (open circles). Paleogeographic reconstruction drawn after ODSN Plate Tectonic Reconstruction Service (http:// www.odsn.de/odsn/services/paleomap/paleomap.html, last access: 8 January 2021).

\section{Material and methods}

\subsection{Material}

All observed samples come from the ODP Site 1260 $\left(9^{\circ} 16^{\prime} \mathrm{N}, 54^{\circ} 32^{\prime} \mathrm{W}\right)$ located on the northwestern margin of Demerara Rise, a submarine plateau off the coast of Surinam and French Guiana (Fig. 1). The site is inferred to have been closer to the Equator during the middle Eocene than today (paleolatitude of $\sim 1^{\circ} \mathrm{N}$; Suganuma and Ogg, 2006). Two closely spaced holes (1260A and 1260B) were drilled via rotary coring, starting at a modern water depth of $2549 \mathrm{~m}$ below sea level. A nearly continuous record of an expanded Albian-Oligocene sequence was recovered (Shipboard Scientific Party, 2004). The middle Eocene interval of the site is characterized by nannofossil chalk, rich in biogenic silica (i.e., opal), with abundant and well-preserved radiolarian fauna (Danelian et al., 2005, 2007) and some other siliceous microfossil groups, including diatoms (Renaudie et al., 2010), ebridians, silicoflagellates, and sponge spicules. The studied sequence is $91.72 \mathrm{~m}$ thick and accumulated in only 3.94 million years, between 43.78 and $39.84 \mathrm{Ma}$ (sedimentation rate evaluated at $\sim 2.3 \mathrm{~m} \mathrm{kyr}^{-1}$ ), during the late middle Eocene (middle Lutetian to early Bartonian). A total of 55 samples were selected from hole 1260A. The sampling was as regular as possible in order to avoid any bias related to heterogeneous bin durations. The average sample spacing is about $1.67 \mathrm{~m}$, and the mean age difference between two successive samples is ca. 71600 years.

An excellent age control for ODP Site 1260 was provided by Westerhold and Röhl (2013), who developed a high-resolution astronomical timescale for this site based on iron $(\mathrm{Fe})$ intensity data obtained by X-ray fluorescence core scanning. Orbitally tuned ages were used to date each sample, and for intervals for which no data were available from hole $1260 \mathrm{~A}$, the absolute age of samples was estimated from 
tuned ages provided for samples situated at the same depth in hole $1260 \mathrm{~B}$.

\subsection{Methods}

Sample preparation followed the protocols described in Sanfilippo et al. (1985). Samples were soaked first in hydrogen peroxide $\left(\mathrm{H}_{2} \mathrm{O}_{2}\right)$, then in hydrochloric acid $(\mathrm{HCl})$ to remove organic matter and carbonate content, respectively. Residues were washed multiple times through a $45 \mu \mathrm{m}$ sieve to eliminate clay, small radiolarian fragments, and diatom frustules; they were then dried over one night at $\sim 40^{\circ} \mathrm{C}$. One to four slides were prepared for each sample by using $\sim 5 \mathrm{mg}$ of cleaned residues scattered homogeneously on a coverslip following the method outlined in Witkowski et al. (2012). When dry, the coverslips were mounted on standard glass slides using Norland Optical Adhesive 61 (refractive index 1.56).

Species identification was conducted using a Zeiss Axio Imager.A2 as a light microscope $(20 \times$ objective lens), fitted with a Zeiss AxioCam ERc5s digital camera. For each illustrated specimen, a batch of 5 to 10 pictures taken at slightly different focal depths were stacked using Helicon Focus v.7.6.6 (HeliconSoft) in order to achieve a composite image of the entire shell. Specimens mounted on a slide were identified to species level where possible. However, as many encountered morphotypes have not been formally described as yet, most of them were not taken into account in this study.

\section{Results}

\subsection{Radiolarian bioevents at hole 1260A}

Radiolaria are abundant and well preserved throughout the studied middle Eocene sequence. Assemblages are taxonomically diverse, with at least 29 families recognized according to the most recent classification provided by Suzuki et al. (2021). The stratigraphic distribution of 61 species, whose first or last occurrence falls in the studied interval, is shown in Fig. 2 (see also Supplement 1 for the occurrence of each studied species per sample). Species concepts used in this study are detailed in the taxonomic Appendix situated at the end of this paper; all species are illustrated in Plates 1-3.

In total, 71 bioevents were recognized at hole 1260A ( 1.8 events per $100 \mathrm{kyr}$ ), including 38 first occurrences (FOs), 29 last occurrences (LOs), and four evolutionary transitions (ETs). These bioevents are summarized in Table 1, with their tuned age at hole 1260A.

\subsection{Correlation between the equatorial Atlantic and Pacific oceans}

Middle Eocene radiolarian bioevents were correlated between ODP Site 1260 and three low-latitudinal sites located in the eastern equatorial Pacific: IODP Sites U1331, U1332, and 1333 (Kamikuri et al., 2012), which have been considered by these authors (and by ourselves) to be a single site, given their geographical proximity (less than $300 \mathrm{~km}$ ). Amongst the 71 radiolarian bioevents mentioned above, documented between zones RP12 and RP16, 31 are common with the equatorial Pacific record and were therefore used for correlation (Fig. 3). The absolute ages provided by Kamikuri et al. (2012) for these radiolarian bioevents were obtained following correlation with the geomagnetic polarity timescale (GPTS) provided by Lourens et al. (2004). However, because the calibration of the GPTS has changed since, we have revised the age-depth models of these Pacific sites by using new ones produced here (see Supplement 2) based on the most recent geomagnetic polarity reversal ages provided by Speijer et al. (2020).

Amongst the primary bioevents, the FO of Podocyrtis $(L$.) goetheana and the ET of Podocyrtis (L.) mitra to Podocyrtis (L.) chalara are nearly isochronous (less than $160 \mathrm{kyr}$ difference) between the equatorial Atlantic and Pacific oceans, while the ET of Podocyrtis (L.) sinuosa to Podocyrtis (L.) mitra and the ET of Podocyrtis (P.) phyxis to Podocyrtis (P.) ampla are slightly diachronous $(\sim 220$ and $\sim 230 \mathrm{kyr}$ difference, respectively). Seven secondary bioevents are also shown to be nearly synchronous (less than $250 \mathrm{kyr}$ difference) and thus reliable for interoceanic correlations. Moreover, given that the order of these bioevents is coherent between the Atlantic and the Pacific oceans they are used for defining new subzones (see Sect. 3.3). These bioevents concern the FOs of species Podocyrtis (P.) apeza, Sethochytris triconiscus, and Zealithapium mitra and the LOs of species Podocyrtis (L.) fasciolata, Podocyrtis (L.) mitra, Podocyrtis (L.) sinuosa, and Podocyrtis (P.) phyxis.

On the other hand, 20 secondary bioevents are shown to be moderately diachronous (between $250 \mathrm{kyr}$ and $1 \mathrm{Ma}$ difference) to highly diachronous (more than $1 \mathrm{Myr}$ difference) between the Atlantic and the Pacific oceans. Moderately diachronous bioevents include the FOs of Dorcadospyris anastasis, Lithocyclia aristotelis group, Podocyrtis (L.) chalara, Podocyrtis (L.) mitra, Podocyrtis (L.) trachodes, and Thyrsocyrtis ( $P$.) tetracantha and the LOs of Artobotrys biaurita, Dictyophimus craticula, Eusyringium lagena, Lithochytris vespertilio, Podocyrtis (L.) trachodes, Podocyrtis (P.) ampla, Zealithapium anoectum, and Zealithapium plegmacantha. Highly diachronous bioevents include the FOs of Cryptocarpium ornatum, Dorcadospyris ombros, Podocyrtis (L.) fasciolata, and Thyrsocyrtis (P.) krooni and the LOs of Anthocyrtoma spp. and Theocotylissa ficus. With the exception of the FOs of Dorcadospyris anastasis, Dorcadospyris ombros, Podocyrtis (L.) chalara, Podocyrtis (L.) fasciolata, Podocyrtis (L.) mitra, and Podocyrtis (L.) trachodes, all these diachronous bioevents occurred earlier in the Atlantic Ocean. 


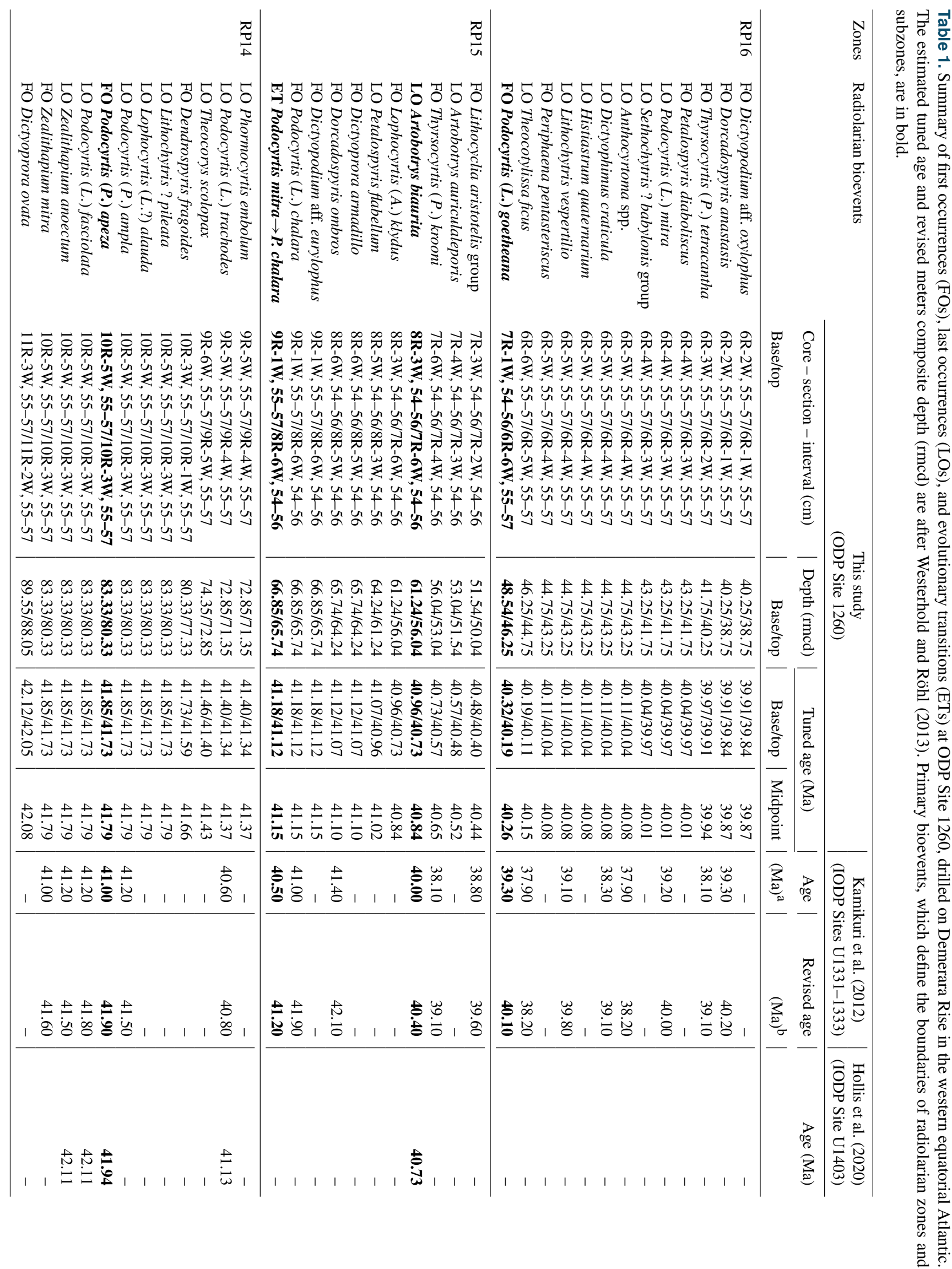




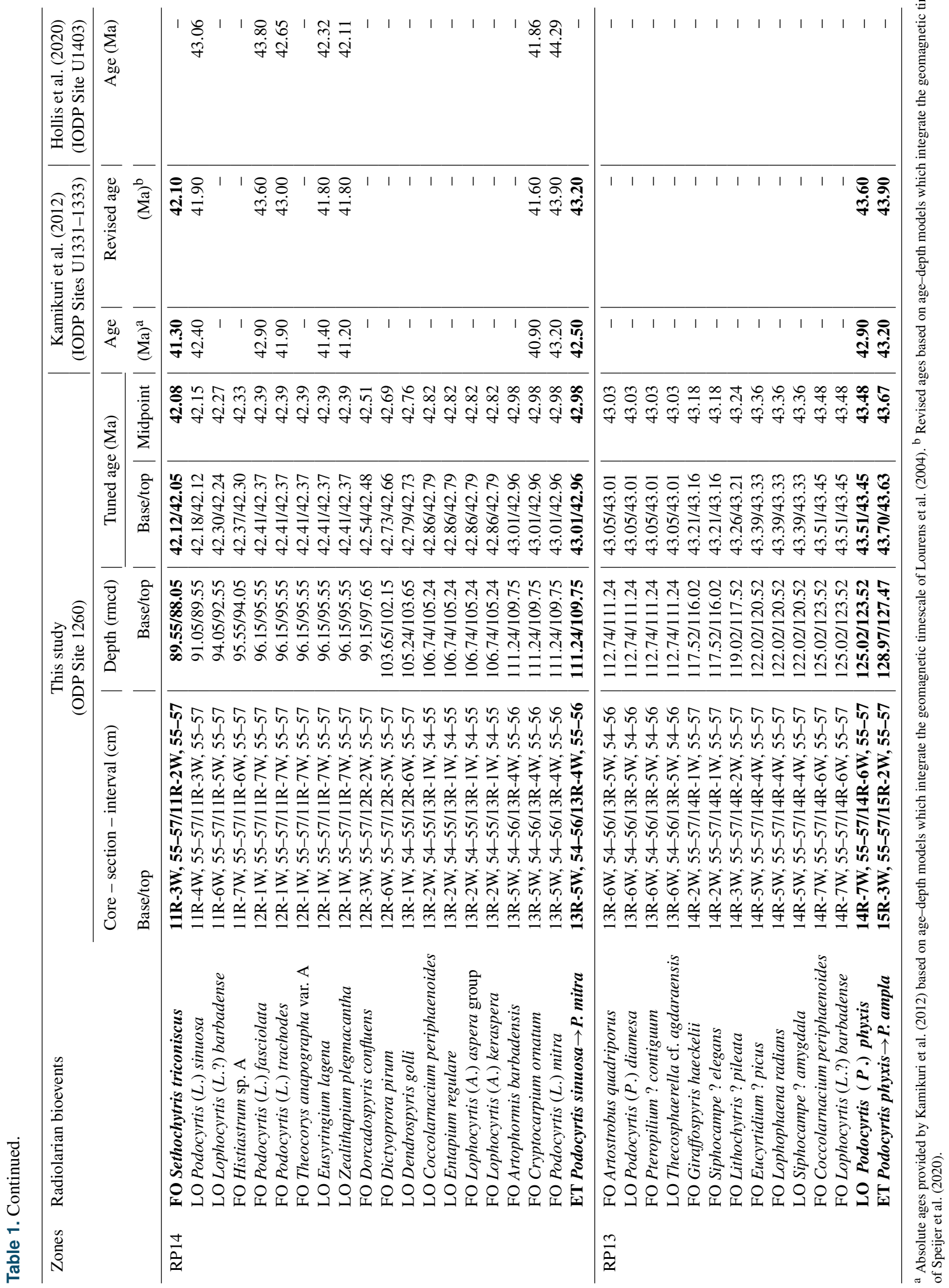




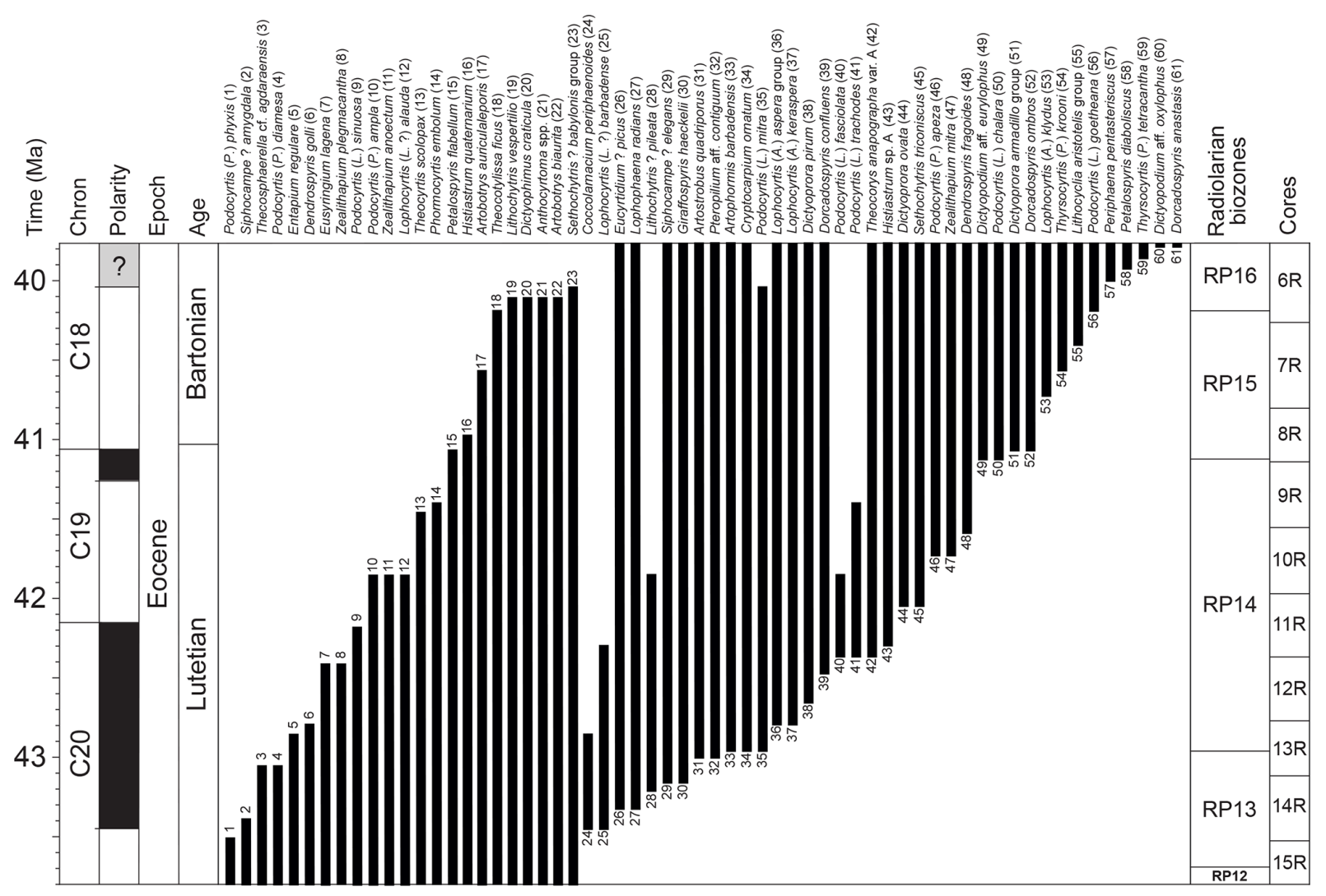

Stratigraphic ranges of selected species

Figure 2. Range chart of 61 selected radiolarian species from the middle Eocene of ODP hole 1260A. Geomagnetic timescale after calibration of Suganuma and Ogg (2006).

\subsection{Correlation between low- and middle-latitude sequences in the North Atlantic Ocean}

Radiolarian bioevents recorded at ODP Site 1260 were also correlated with the northwestern Atlantic IODP Site U1403 (Hollis et al., 2020). A total of 298 radiolarian bioevents were documented at this site, amongst which 29 are common with the record in the equatorial Atlantic sequence and were thus used for correlation (Fig. 4). The absolute ages provided by Hollis et al. (2020) for these radiolarian bioevents were obtained by calibration to the latest version of the GTS Paleogene timescale (Speijer et al., 2020) using calcareous nannofossils biostratigraphy and magnetostratigraphy.

Three secondary bioevents are found to be nearly isochronous (less than $160 \mathrm{kyr}$ difference) between low and middle latitudes in the North Atlantic Ocean, including the FO of Podocyrtis (P.) apeza and the LOs of Artobotrys biaurita and Eusyringium lagena. On the other hand, nine secondary bioevents are shown to be moderately $(250 \mathrm{kyr}$ to $1 \mathrm{Myr}$ difference) to highly diachronous (more than $1 \mathrm{Myr}$ difference) between low and middle latitudes. Moderately diachronous bioevents include the FO of Podocyrtis $(L$.) trachodes and the LOs of Podocyrtis (L.) fasciolata, Podocyrtis (L.) trachodes, Zealithapium mitra, and Zealithapium pleg- macantha. Highly diachronous bioevents include the FOs of Cryptocarpium ornatum, Podocyrtis (L.) fasciolata, and Podocyrtis (L.) mitra and the LO of Podocyrtis (L.) sinuosa.

\subsection{Established radiolarian biozones and new subzones}

Five biozones of the tropical radiolarian biozonation of Sanfilippo and Nigrini (1998) were recognized for our studied sequence; they correspond to the upper part of zone RP12, the entire zones RP13, RP14, and RP15, and the lower part of zone RP16. As mentioned above, the correlation of a number of common bioevents between the Atlantic (ODP Site 1260 and IODP Site U1403; see Fig. 4) and the Pacific (IODP Sites U1331, U1332, and U1333; see Fig. 3) allows us to subdivide the RP13 zone into two subzones (Siphocampe? amygdala subzone - RP13a - and Coccolarnacium periphaenoides subzone - RP13b), the RP14 zone into three subzones ( $A r$ tostrobus quadriporus subzone - RP14a, Sethochytris triconiscus subzone - RP14b, and Podocyrtis (Podocyrtopsis) apeza subzone - RP14c), and the RP15 zone into two subzones (Artobotrys biaurita subzone - RP15a - and Thyrsocyrtis (Pentalocorys) krooni subzone - RP15b) (Fig. 5). The pre-established radiolarian zones and the newly defined sub- 


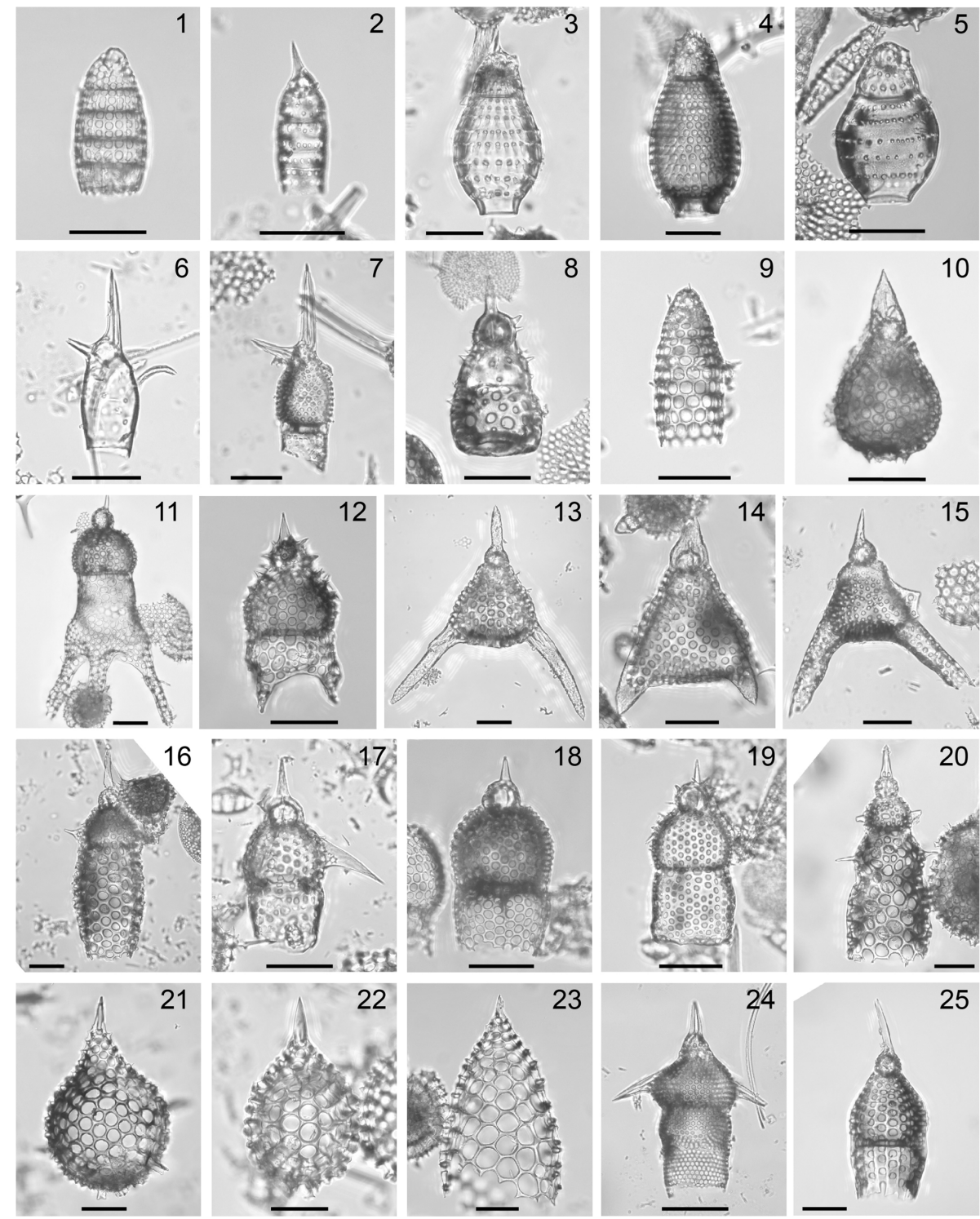

Plate 1. Composite light micrographs of selected radiolarians from ODP Site 1260. All scale bars equal 50 $\mu$ m. (1) Siphocampe ? amygdala (Shilov), sample: ODP 1260A-15R-4W, 55-57 cm, slide: USTL 3549; (2) Siphocampe ? elegans (Ehrenberg), sample: ODP 1260A-6R-3W, 55-57 cm, slide: USTL 3424; (3) Dictyoprora ovata (Haeckel), sample: ODP 1260A-9R-3W, 55-57 cm, slide: USTL 3477; (4) Dictyoprora armadillo (Ehrenberg) group, sample: ODP 1260A-6R-3W, 55-57 cm, slide: USTL 3426; (5) Dictyoprora pirum (Ehrenberg), sample: ODP 1260A-6R-2W, 55-57 cm, slide: USTL 3421; (6) Artobotrys biaurita (Ehrenberg), sample: ODP 1260A-9R-3W, 55-57 cm, slide: USTL 3477; (7) Artobotrys auriculaleporis (Clark and Campbell), sample: ODP 1260A-9R-4W, 55-57 cm, slide: USTL 3481; (8) Theocorys anapographa Riedel and Sanfilippo var. A, sample: ODP 1260A-6R-3W, 55-57 cm, slide: USTL 3424; (9) Artostrobus quadriporus Bjørklund, sample: ODP 1260A-6R-3W, 55-57 cm, slide: USTL 3424; (10) Eusyringium lagena (Ehrenberg), sample: ODP 1260A-15R-4W, 55-57 cm, slide: USTL 3550; (11) Dictyopodium aff. eurylophus, sample: ODP 1260A-6R-2W, 55-57 cm, slide: USTL 3423; (12) Dictyopodium aff. oxylophus, sample: ODP 1260A-6R-1W, 55-57 cm, slide: USTL 3419; (13) Sethochytris ? babylonis (Clark and Campbell) group, sample: ODP 1260A-11R-1W, 55-57 cm, slide: USTL 3500; (14) Lithochytris ? pileata Ehrenberg, sample: ODP 1260A-11R-7W, 55-57 cm, slide: USTL 3506; (15) Sethochytris triconiscus Haeckel, sample: ODP 1260A-9R-6W, 55-57 cm, slide: USTL 3489; (16) Lophocyrtis (Lophocyrtis ?) alauda (Ehrenberg), sample: ODP 1260A-13R-6W, 54-56 cm, slide: USTL 3527; (17) Lophocyrtis (Lophocyrtis ?) barbadense (Ehrenberg), sample: ODP 1260A-13R-5W, 55-56 cm, slide: USTL 3524; (18) Lophocyrtis (Apoplanius) aspera (Ehrenberg) group, sample: ODP 1260A-10R-4W, 55-57 cm, slide: USTL 3496; (19) Lophocyrtis (Apoplanius) keraspera Sanfilippo and Caulet, sample: ODP 1260A13R-5W, 55-56 cm, slide: USTL 3524; (20) Lophocyrtis (Apoplanius) klydus Sanfilippo and Caulet, sample: ODP 1260A-6R-6W, 55-57 cm, slide: USTL 3436; (21) Zealithapium plegmacantha (Riedel and Sanfilippo), sample: ODP 1260A-14R-1W, 55-57 cm, slide: USTL 3530; (22) Zealithapium anoectum (Riedel and Sanfilippo), sample: ODP 1260A-12R-3W, 55-57 cm, slide: USTL 3512; (23) Zealithapium mitra (Ehrenberg), sample: ODP 1260A-7R-4W, 54-56 cm, slide: USTL 3451; (24) Pteropilium aff. contiguum, sample: ODP 1260A-9R-4W, 55-57 cm, slide: USTL 3481; (25) Theocyrtis scolopax (Ehrenberg), sample: ODP 1260A-10R-6W, 55-57 cm, slide: USTL 3498. 

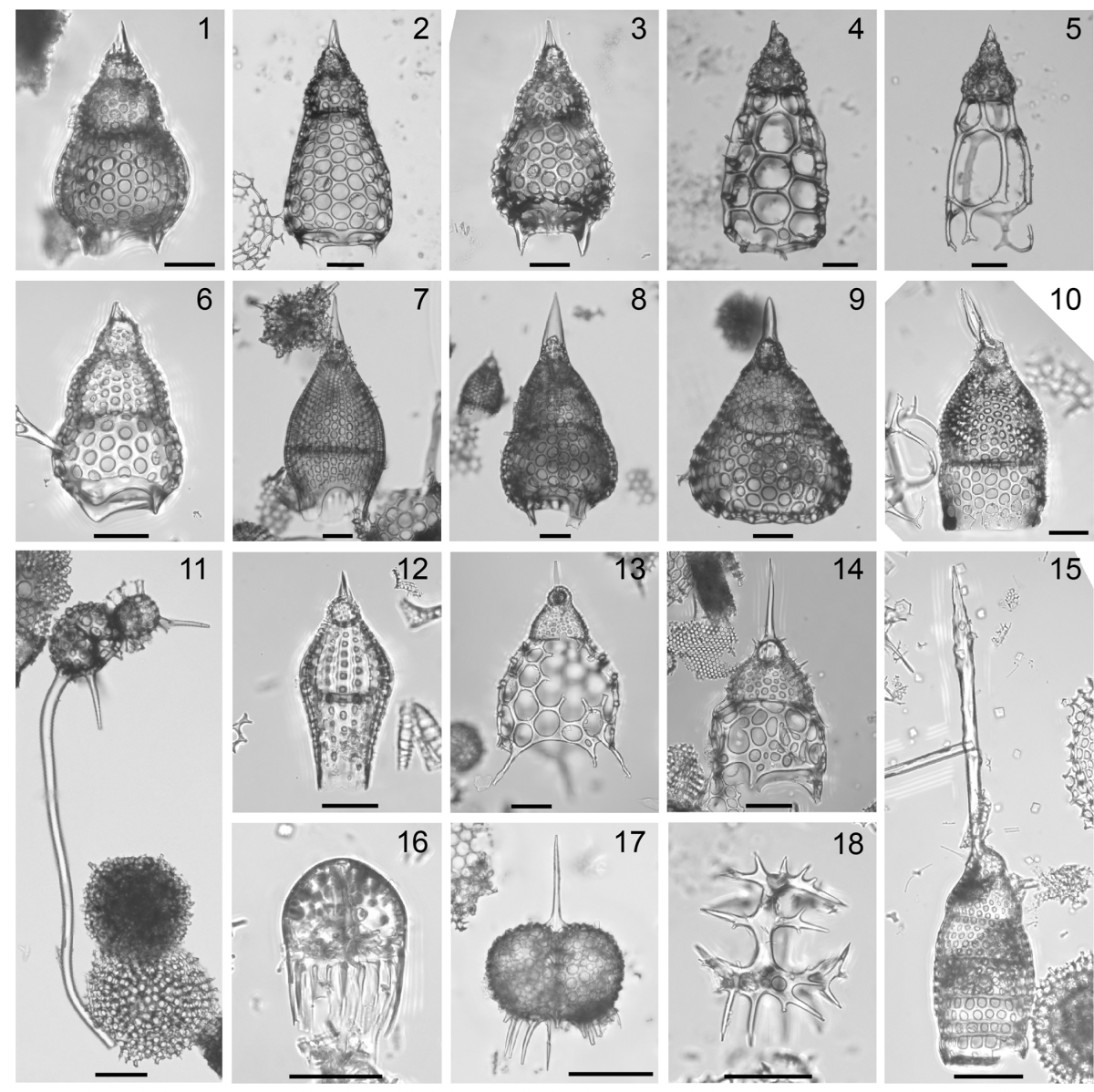

15
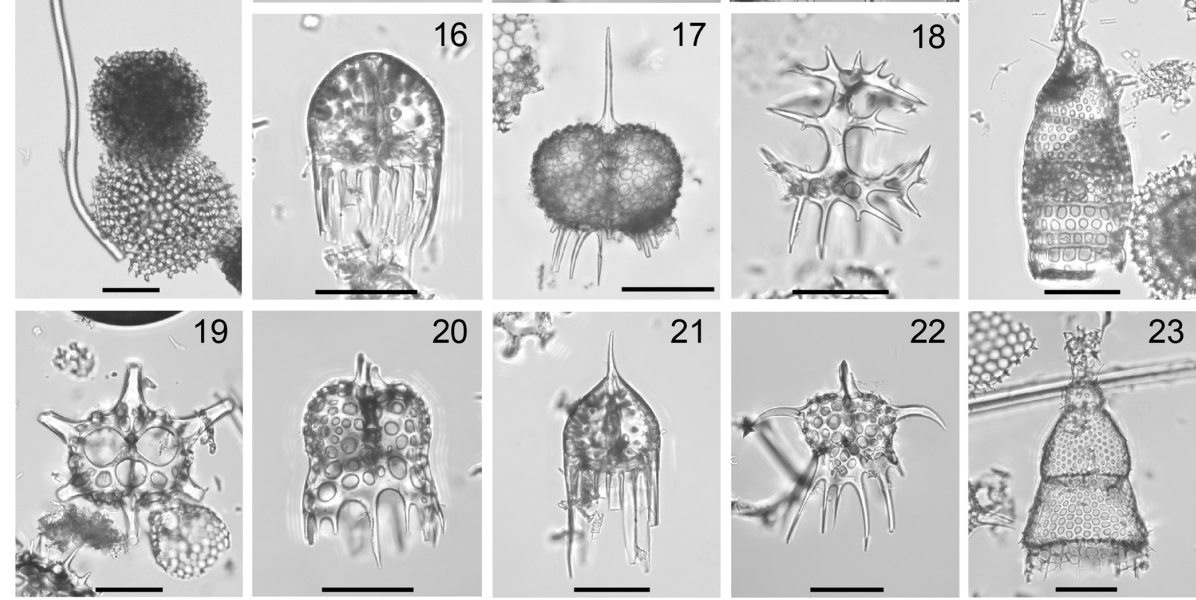

Plate 2. Composite light micrographs of selected radiolarians from ODP Site 1260. All scale bars equal 50 $\mu$ m. (1) Podocyrtis (Lampterium) sinuosa Ehrenberg, sample: ODP 1260A-15R-4W, 55-57 cm, slide: USTL 3552; (2) Podocyrtis (Lampterium) mitra Ehrenberg, sample: ODP 1260A-9R-3W, 55-57 cm, slide: USTL 3477; (3) Podocyrtis (Lampterium) trachodes Riedel and Sanfilippo, sample: ODP 1260A-10R-6W, 55-57 cm, slide: USTL 3498; (4) Podocyrtis (Lampterium) chalara Riedel and Sanfilippo, sample: ODP 1260A-6R-6W, 55-57 cm, slide: USTL 3436; (5) Podocyrtis (Lampterium) goetheana (Haeckel), sample: ODP 1260A-6R-2W, 55-57 cm, slide: USTL 3420; (6) Podocyrtis (Lampterium) fasciolata Nigrini, sample: ODP 1260A-11R-7W, 55-57 cm, slide: USTL 3506; (7) Podocyrtis (Podocyrtoges) diamesa Riedel and Sanfilippo, sample: ODP 1260A-15R-2W, 55-57 cm, slide: USTL 3543; (8) Podocyrtis (Podocyrtoges) phyxis Sanfilippo and Riedel, sample: ODP 1260A-15R-2W, 55-57 cm, slide: USTL 3543; (9) Podocyrtis (Podocyrtoges) ampla Ehrenberg, sample: ODP 1260A-10R6W, 55-57 cm, slide: USTL 3498; (10) Podocyrtis (Podocyrtopsis) apeza Sanfilippo and Riedel, sample: ODP 1260A-6R-2W, 55-57 cm, slide: USTL 3421; (11) Dorcadospyris anastasis Sanfilippo in Nigrini et al., sample: ODP 1260A-6R-1W, 55-57 cm, slide: USTL 3419; (12) Phormocyrtis embolum (Ehrenberg), sample: ODP 1260A-13R-1W, 54-55 cm, slide: USTL 3522; (13) Thyrsocyrtis (Pentalocorys) tetracantha (Ehrenberg), sample: ODP 1260A-6R-2W, 55-57 cm, slide: USTL 3420; (14) Thyrsocyrtis (Pentalocorys) krooni Sanfilippo and Moore, sample: ODP 1260A-6R-2W, 55-57 cm, slide: USTL 3421; (15) Eucyrtidium ? picus Ehrenberg, sample: ODP 1260A-13R-4W, 5557 cm, slide: USTL 2854; (16) Dendrospyris fragoides Sanfilippo and Riedel, sample: ODP 1260A-9R-3W, 55-57 cm, slide: USTL 3478; (17) Dendrospyris golli Nishimura, sample: ODP 1260A-15R-4W, 55-57 cm, slide: USTL 3550; (18) Giraffospyris haeckelii (Bütschli), sample: ODP 1260A-9R-3W, 55-57 cm, slide: USTL 3477; (19) Dorcadospyris ombros Sanfilippo in Nigrini et al., sample: ODP 1260A7R-6W, 54-56 cm, slide: USTL 3454; (20) Dorcadospyris confluens (Ehrenberg), sample: ODP 1260A-6R-1W, 55-57 cm, slide: USTL 3419; (21) Petalospyris flabellum Ehrenberg, sample: ODP 1260A-10R-6W, 55-57 cm, slide: USTL 3498; (22) Petalospyris diaboliscus Ehrenberg, sample: ODP 1260A-6R-1W, 55-57 cm, slide: USTL 3419; (23) Artophormis barbadensis (Ehrenberg), sample: ODP 1260A-6R-2W, 55$57 \mathrm{~cm}$, slide: USTL 3420 . 


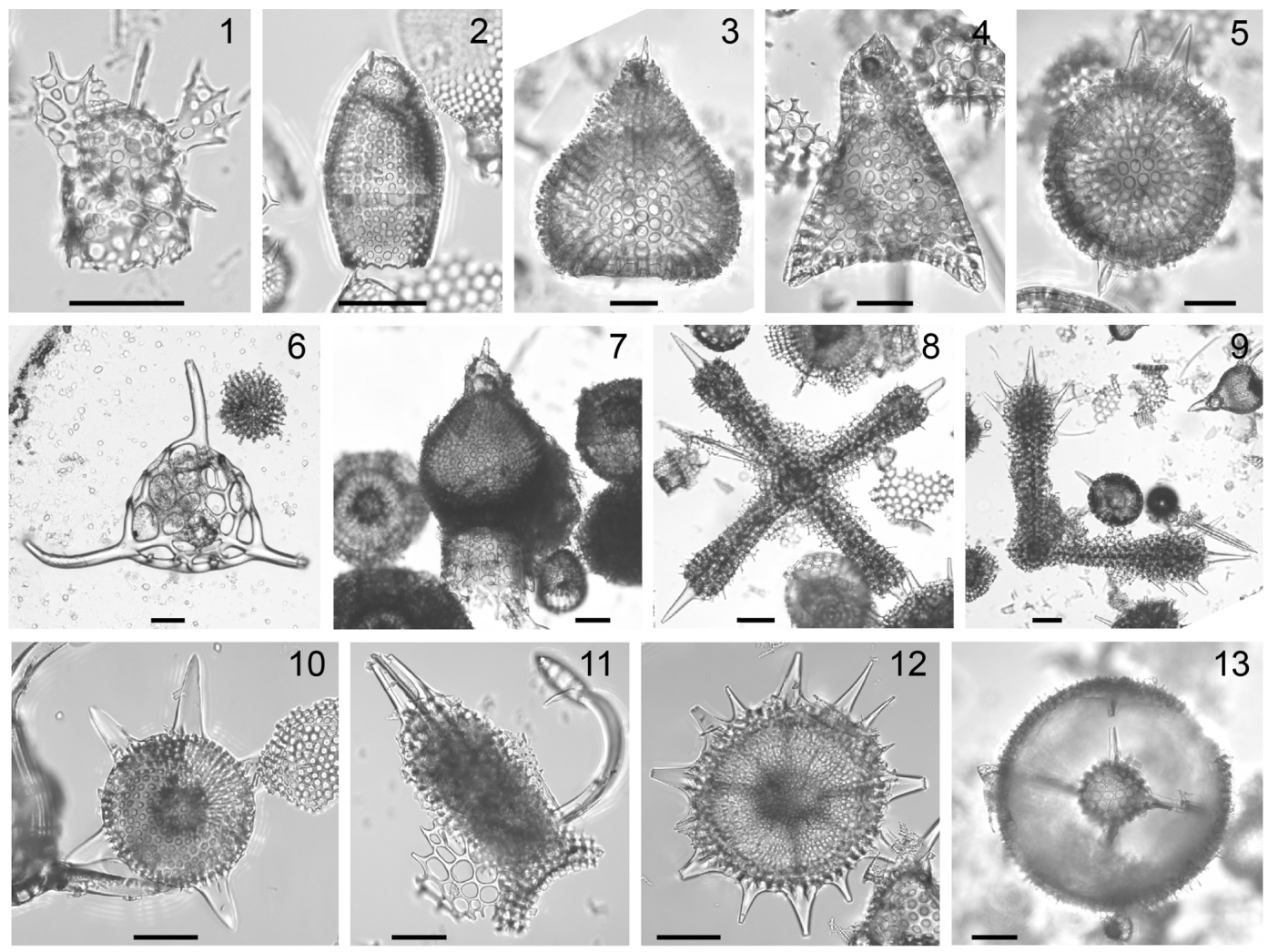

Plate 3. Composite light micrographs of selected radiolarians from ODP hole 1260A. All scale bars equal 50 $\mu$ m. (1) Lophophaena radians Ehrenberg, Sample: ODP 1260A-9R-3W, 55-57 cm, slide: USTL 3477; (2) Cryptocarpium ornatum (Ehrenberg), sample: ODP 1260A6R-2W, 55-57 cm, slide: USTL 3420; (3) Theocotylissa ficus (Ehrenberg), sample: ODP 1260A-15R-2W, 55-57 cm, slide: USTL 3543; (4) Lithochytris vespertilio Ehrenberg, sample: ODP 1260A-16R-1W, 55-57 cm, slide: USTL 3558; (5) Thecosphaerella aff. agdaraensis (Mamedov), sample: ODP 1260A-15R-2W, 55-57 cm, slide: USTL 3543; (6) Dictyophimus craticula Ehrenberg, sample: ODP 1260A15R-4W, 55-57 cm, slide: USTL 3551; (7) Anthocyrtoma spp., sample: ODP 1260A-13R-4W, 55-57 cm, slide: USTL 2854; (8) Histiastrum quaternarium Ehrenberg, sample: ODP 1260A-13R-5W, 54-56 cm, slide: USTL 3525; (9) Histiastrum sp. A, sample: ODP 1260A-6R-1W, 55-57 cm, slide: USTL 3419; (10) Periphaena pentasteriscus (Clark and Campbell), sample: ODP 1260A-6R-2W, 55-57 cm, slide: USTL 3422; (11) Lithocyclia aristotelis (Ehrenberg) group, sample: ODP 1260A-6R-3W, 55-57 cm, slide: USTL 3425; (12) Coccolarnacium periphaenoides Dumitrică, sample: ODP 1260A-13R-2W, 54-55 cm, slide: USTL 2852; (13) Entapium regulare Sanfilippo and Riedel, sample: ODP 1260A-14R-6W, 55-57 cm, slide: USTL 3537.

zones are given below in stratigraphic order, with their formal definitions, their magnetostratigraphic calibrations, and their absolute age obtained by the orbital time framework provided for ODP Site 1260 (Westerhold and Röhl, 2013). First occurrences are shown as FO, last occurrences as LO, and evolutionary transitions as ET.

RP16 - Podocyrtis (Lampterium) goetheana interval zone (Moore, 1971, emend. Riedel and Sanfilippo, 1978)

\section{Definition}

Biostratigraphic interval between the FO of Podocyrtis (Lampterium) goetheana (Haeckel) (base) and the FO of Cryptocarpium azyx (Sanfilippo and Riedel) (top).

\section{Occurrence at hole $1260 \mathrm{~A}$}

The base of this zone is located between samples ODP 1260A-7R-1W, 54-56 cm (48.54 rmcd) and ODP 1260A-6R$6 \mathrm{~W}, 55-57 \mathrm{~cm}(46.25 \mathrm{rmcd})$.

\section{Estimated age}

The base of the zone is dated in the equatorial Atlantic at 40.26 Ma (Westerhold and Röhl, 2013) and 40.1 Ma in the equatorial Pacific (Kamikuri et al., 2012; revised age in this study); middle Eocene (early Bartonian).

\section{Magnetostratigraphic calibration}

The base of this zone is placed within the uppermost part of Chron C18r at both the Atlantic (this study, in combination 


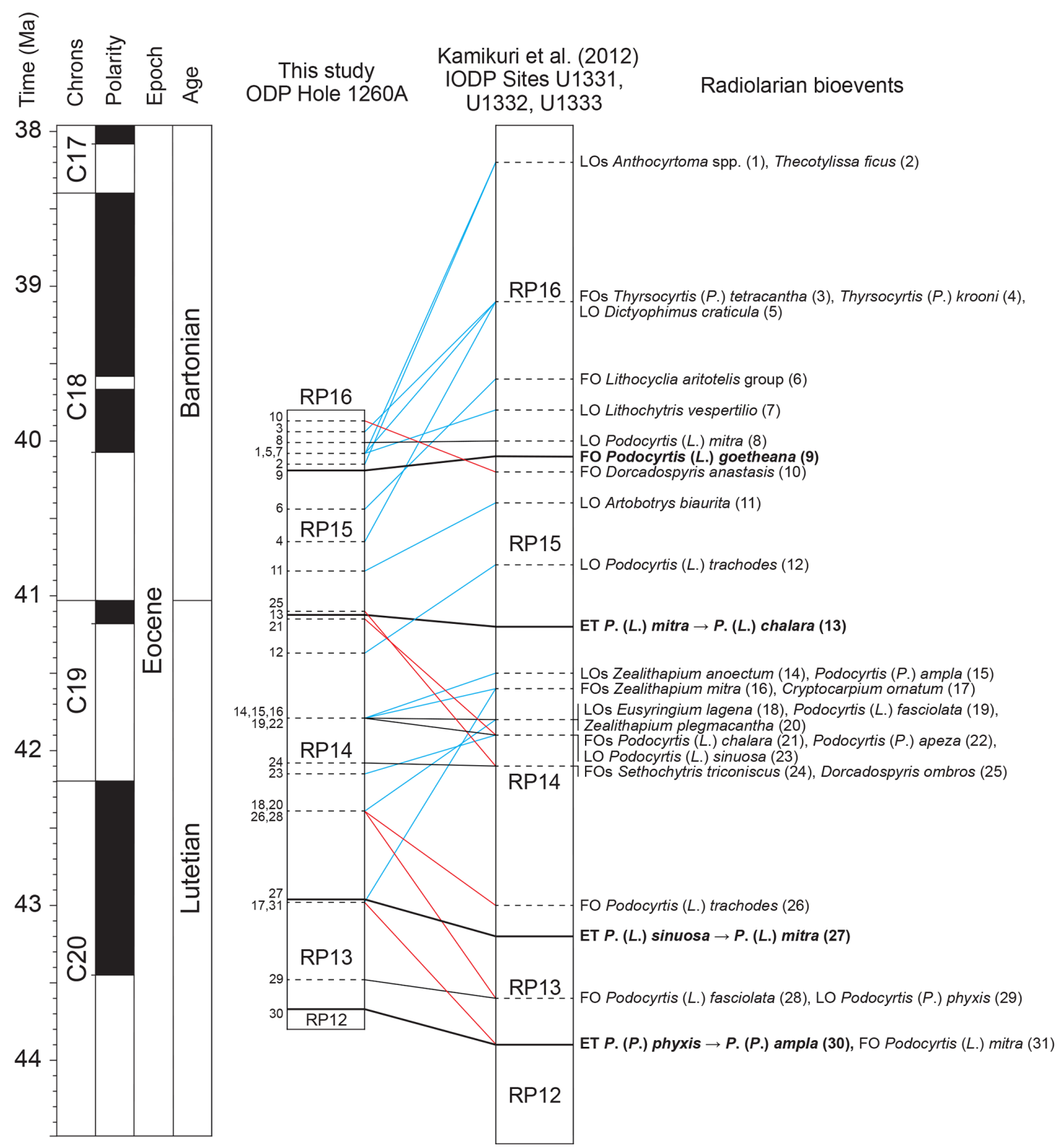

Figure 3. Correlation of radiolarian bioevents between ODP hole 1260A (this study) and IODP Sites U1331, U1332, and U1333 (Kamikuri et al., 2012). Black lines represent nearly synchronous bioevents, blue lines represent diachronous bioevents which first occur in the Atlantic Ocean, and red lines represent diachronous bioevents which first occur in the Pacific Ocean. The geomagnetic timescale is after Speijer et al. (2020).

with Suganuma and Ogg, 2006) and Pacific sites (Kamikuri et al., 2012; revised calibration in this study).

\section{Secondary bioevents}

Five FOs (Dictyopodium aff. oxylophus, Dorcadospyris anastasis, Thyrsocyrtis (P.) tetracantha, Petalospyris diaboliscus, and Periphaena pentasteriscus) and seven LOs (Podocyrtis (L.) mitra, Sethochytris ? babylonis group, Anthocyrtoma spp., Dictyophimus craticula, Histiastrum quaternarium, Lithochytris vespertilio, and Theocotylissa ficus).

\section{Remarks}

The record of zone RP16 is truncated at hole 1260A. It corresponds to the entire core $6 \mathrm{R}$, above which $(>38.2 \mathrm{rmcd}$ ) samples contain only rare and/or non-diagnostic radiolarian fragments. Therefore, most of the zone RP16 and related bioevents are missing, including the FOs of Cryptocarpium azyx and Thyrsocyrtis bromia, some short-lived Dorcadospyris species found in the equatorial Pacific (e.g., Dorcadospyris copelata; Nigrini et al., 2005), and the acme of Podocyrtis goetheana. At ODP hole 1260A, the base of zone RP16 is 


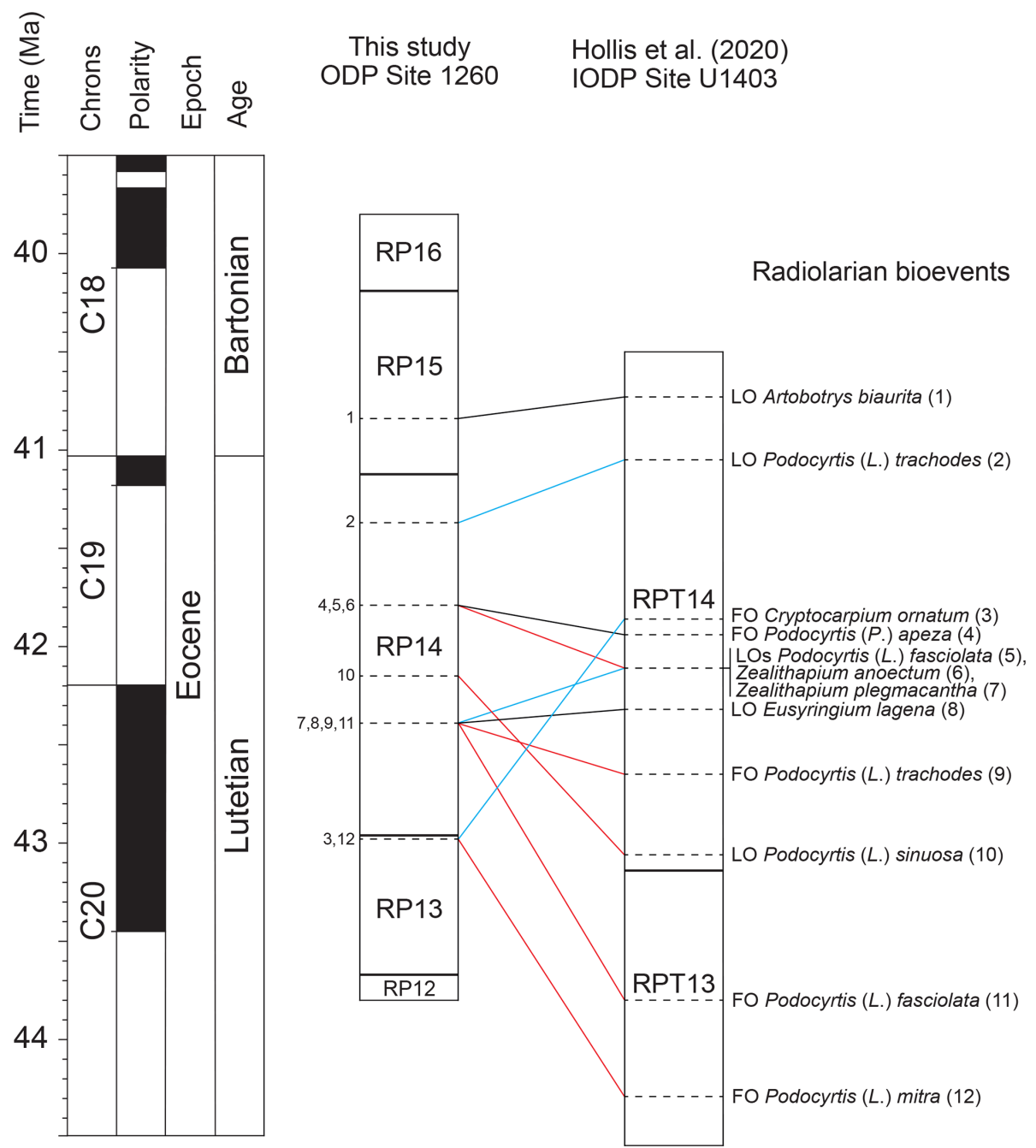

Figure 4. Correlation of radiolarian bioevents between ODP Site 1260 (this study) and IODP Site U1403 (Hollis et al., 2020). Black lines represent nearly synchronous bioevents, blue lines represent diachronous bioevents which first occur at ODP Site 1260, and red lines represent diachronous bioevents which first occur at IODP Site U1403. The geomagnetic timescale is after Speijer et al. (2020).

correlated with the upper part of the planktic foraminifera zone $\mathrm{P} 13$, and the basal datum is approximately synchronous with the LO of the nannofossil species Chiasmolithus solitus, which defined the base of the Discoaster saipanensis zone (NP17).

\section{RP15 - Podocyrtis (Lampterium) chalara}

lineage zone (Riedel and Sanfilippo, 1970, 1978)

\section{Definition}

Biostratigraphic interval between the ET from Podocyrtis (Lampterium) mitra Ehrenberg to Podocyrtis (Lampterium) chalara Riedel and Sanfilippo (base), and the FO of Podocyrtis (Lampterium) goetheana (Haeckel) (top).

\section{Occurrence at hole $1260 \mathrm{~A}$}

Base: from sample ODP 1260A-9R-1W, $55-57 \mathrm{~cm}$ $(66.85 \mathrm{rmcd})$ to sample ODP $1260 \mathrm{~A}-8 \mathrm{R}-6 \mathrm{~W}, \quad 54-56 \mathrm{~cm}$ $(65.74 \mathrm{rmcd})$. Top: from sample ODP 1260A-7R-1W, $54-56 \mathrm{~cm}$ (48.54 rmcd) to sample ODP $1260 \mathrm{~A}-6 \mathrm{R}-6 \mathrm{~W}$, $55-57 \mathrm{~cm}(46.25 \mathrm{rmcd})$.

\section{Estimated age}

From 41.15 to $40.26 \mathrm{Ma}$ in the equatorial Atlantic (Westerhold and Röhl, 2013) and from 41.2 to $40.1 \mathrm{Ma}$ in the equatorial Pacific (Kamikuri et al., 2012; revised ages); middle Eocene (late Lutetian to early Bartonian). 


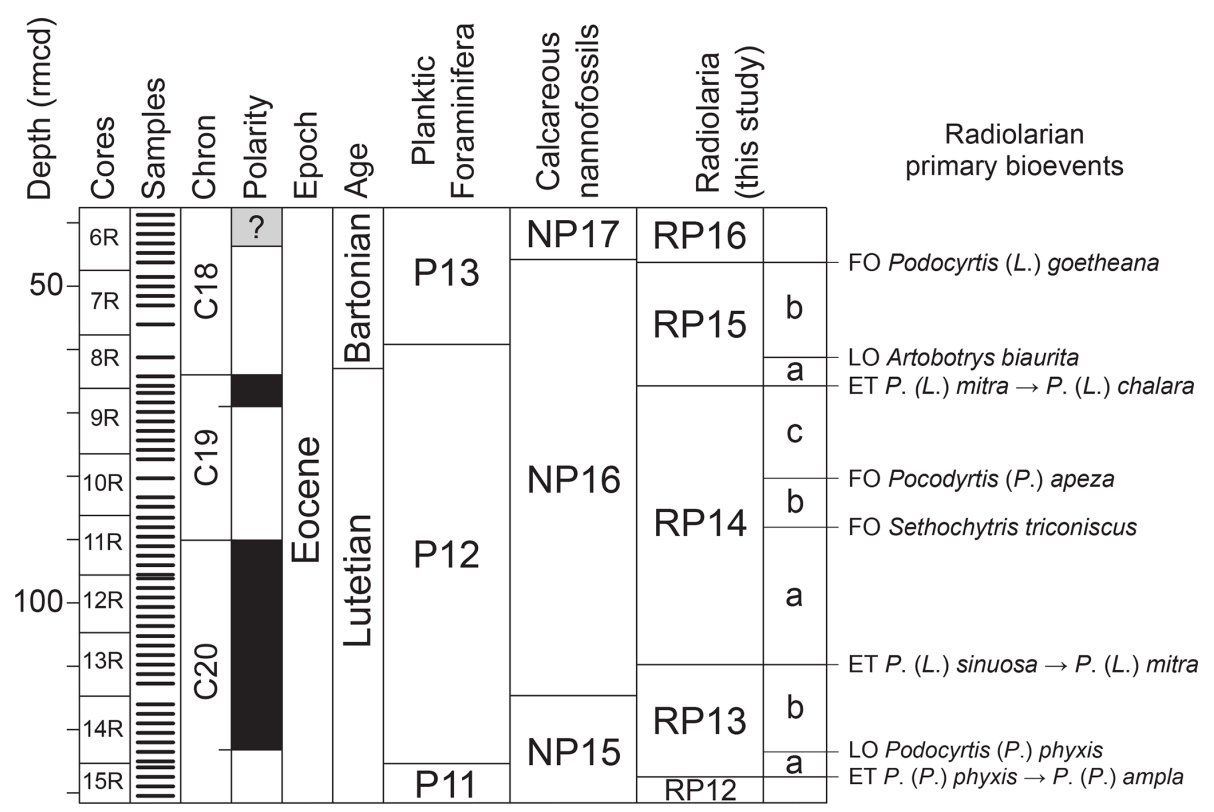

Figure 5. Biostratigraphic summary of calcareous and siliceous microfossils at ODP Site 1260 after the biostratigraphic results of the Shipboard Scientific Party (2004) and of this study, including the newly defined radiolarian subzones. The geomagnetic timescale used is after Suganuma and Ogg (2006). FO: first occurrence, LO: last occurrence, ET: evolutionary transition.

\section{Magnetostratigraphic calibration}

The basal datum is placed within Chron C19n in the equatorial Atlantic (this study in combination with Suganuma and Ogg, 2006), while it falls within the uppermost part of Chron C19r in the equatorial Pacific (Kamikuri et al., 2012; revised calibration in this study). The top of the zone is placed within the uppermost part of Chron C18r at both the Atlantic (this study in combination with Suganuma and Ogg, 2006) and Pacific sites (Kamikuri et al., 2012; revised calibration in this study).

\section{Secondary bioevents}

Seven FOs (Lithocyclia aristotelis group, Thyrsocyrtis $(P$.) krooni, Lophocyrtis (A.) klydus, Dictyoprora armadillo, Dorcadospyris ombros, Dictyopodium aff. eurylophus, and Podocyrtis (L.) chalara) and three LOs (Artobotrys auriculaleporis, Artobotrys biaurita, and Petalospyris flabellum).

\section{Remarks}

At ODP hole 1260A, this zone is correlated with the uppermost part of the planktic foraminifera zone P12 to the lower part of zone P13 and with the upper part of nannofossil zone NP16. The Lutetian-Bartonian boundary is placed within this zone at $\sim 63.17 \mathrm{rmcd}(41.03 \mathrm{Ma})$, between samples ODP 1260A-8R-6W, 54-56 cm (65.74 rmcd) and ODP 1260A-8R-5W, 54-56 cm (64.24 rmcd). This zone is divided into lower (a) and upper (b) subzones.

\section{RP15b - Thyrsocyrtis (Pentalocorys) krooni interval subzone, new subzone}

\section{Definition}

Biostratigraphic interval between the LO of Artobotrys biaurita (Ehrenberg) (base) and the FO of Podocyrtis (Lampterium) goetheana (Haeckel) (top).

\section{Occurrence at hole $1260 \mathrm{~A}$}

Base: from sample ODP 1260A-8R-3W, $54-56 \mathrm{~cm}$ $(61.24 \mathrm{rmcd})$ to sample ODP $1260 \mathrm{~A}-7 \mathrm{R}-6 \mathrm{~W}, 54-56 \mathrm{~cm}$ (56.04 rmcd). Top: from sample ODP 1260A-7R-1W, $54-56 \mathrm{~cm}$ (48.54 rmcd) to sample ODP 1260A-6R-6W, $55-57 \mathrm{~cm}(46.25 \mathrm{rmcd})$.

\section{Estimated age}

From 40.84 to $40.26 \mathrm{Ma}$ in the equatorial Atlantic (Westerhold and Röhl, 2013) and from 40.4 to $40.1 \mathrm{Ma}$ in the equatorial Pacific (Kamikuri et al., 2012; revised ages in this study); middle Eocene (early Bartonian).

\section{Magnetostratigraphic calibration}

The new subzone falls completely in Chron C18r at both the Atlantic (this study in combination with Suganuma and Ogg, 2006) and Pacific sites (Kamikuri et al., 2012; revised calibration in this study). 


\section{Remarks}

The basal datum is nearly isochronous between ODP hole 1260A (40.84 Ma) and IODP Site U1403 (40.73 Ma), while it is moderately diachronous between ODP hole 1260A (40.84 Ma) and IODP Sites U1331, U1332, and U1333 (40.40 Ma). However, at each equatorial site the FO of Artobotrys biaurita is close to the FO of Orbulinoides beckmanni, which defines the base of the planktic foraminifera zone P13. Moreover, the FO of Artobotrys biaurita appears to be synchronous at the scale of the eastern equatorial Pacific (Nigrini et al., 2005). As indicated above, this subzone is correlated at ODP hole $1260 \mathrm{~A}$ with the uppermost part of the planktic foraminifera zone P12 to the lower part of zone P13 and the upper part of nannofossil zone NP16.

RP15a - Artobotrys biaurita

interval subzone, new subzone

\section{Definition}

Biostratigraphic interval between the ET from Podocyrtis (Lampterium) mitra Ehrenberg, to Podocyrtis (Lampterium) chalara Riedel and Sanfilippo (base), and the LO of Artobotrys biaurita (Ehrenberg) (top).

\section{Occurrence at hole 1260A}

Base: from sample ODP 1260A-9R-1W, $55-57 \mathrm{~cm}$ $(66.85 \mathrm{rmcd})$ to sample ODP $1260 \mathrm{~A}-8 \mathrm{R}-6 \mathrm{~W}, 54-56 \mathrm{~cm}$ $(65.74 \mathrm{rmcd})$. Top: from sample ODP 1260A-8R-3W, $54-56 \mathrm{~cm}(61.24 \mathrm{rmcd})$ to sample ODP 1260A-7R-6W, $54-56 \mathrm{~cm}(56.04 \mathrm{rmcd})$.

\section{Estimated age}

From 41.15 to $40.84 \mathrm{Ma}$ in the equatorial Atlantic (Westerhold and Röhl, 2013) and from 41.2 to 40.4 Ma in the equatorial Pacific (Kamikuri et al., 2012; revised ages in this study); middle Eocene (late Lutetian to early Bartonian).

\section{Magnetostratigraphic calibration}

The base of the zone falls within Chron C19n and the top in Chron C18r at both the Atlantic (this study in combination with Suganuma and Ogg, 2006) and Pacific sites (Kamikuri et al., 2012; revised calibration in this study).

\section{Remarks}

The basal datum is synchronous with the FOs of Dictyopodium aff. eurylophus at ODP hole 1260A. This subzone corresponds to the uppermost part of planktic foraminifera zone P12 and the nannofossil zone NP16. The LutetianBartonian boundary is found in this subzone.
RP14 - Podocyrtis (Lampterium) mitra lineage zone (Riedel and Sanfilippo, 1970, 1978)

\section{Definition}

Biostratigraphic interval between the ET from Podocyrtis (Lampterium) sinuosa Ehrenberg, to Podocyrtis (Lampterium) mitra Ehrenberg (base), and the ET from Podocyrtis (Lampterium) mitra Ehrenberg, to Podocyrtis (Lampterium) chalara Riedel and Sanfilippo (top).

\section{Occurrence at hole $1260 \mathrm{~A}$}

Base: from sample ODP 1260A-13R-5W, 54-56 cm (111.24 rmcd) to sample ODP 1260A-13R-4W, 55-56 cm (109.75 rmcd). Top: from sample ODP 1260A-9R-1W, $55-57 \mathrm{~cm}(66.85 \mathrm{rmcd})$ to sample ODP $1260 \mathrm{~A}-8 \mathrm{R}-6 \mathrm{~W}$, $54-56 \mathrm{~cm}(65.74 \mathrm{rmcd})$.

\section{Estimated age}

From 42.98 to $41.15 \mathrm{Ma}$ in the equatorial Atlantic (Westerhold and Röhl, 2013) and from 43.2 to 41.2 Ma in the equatorial Pacific (Kamikuri et al., 2012; revised ages in this study); middle Eocene (late Lutetian).

\section{Magnetostratigraphic calibration}

The base of the zone is placed within Chron C20n and the top within Chron C19n at both the Atlantic (this study in combination with Suganuma and Ogg, 2006) and Pacific sites (Kamikuri et al., 2012; revised calibration in this study).

\section{Secondary bioevents}

A total of 16 FOs (Dendrospyris fragoides, Podocyrtis (P.) apeza, Zealithapium mitra, Dictyoprora ovata, Sethochytris triconiscus, Histiastrum sp. A, Podocyrtis (L.) fasciolata, Podocyrtis (L.) trachodes, Theocorys anapographa var. A, Dorcadospyris confluens, Dictyoprora pirum, Lophocyrtis (A.) aspera group, Lophocyrtis (A.) keraspera, Artophormis barbadensis, Cryptocarpium ornatum, and Podocyrtis (L.) mitra) and 15 LOs (Phormocyrtis embolum, Podocyrtis (L.) trachodes, Theocorys scolopax, Lophocyrtis (L.?) alauda, Lithochytris ? pileata, Podocyrtis (P.) ampla, Podocyrtis (L.) fasciolata, Zealithapium anoectum, Podocyrtis (L.) sinuosa, Lophocyrtis (L.?) barbadense, Eusyringium lagena, Zealithapium plegmacantha, Dendrospyris golli, Coccolarnacium periphaenoides, Entapium regulare).

\section{Remarks}

This zone is the longest at ODP hole 1260A, covering $46 \%$ of the studied interval and including almost half of the recognized bioevents. Radiolarian zone RP14 is correlated with 
the planktic foraminifera zone P12 and the nannofossil zone NP16. This zone is subdivided into three subzones.

RP14c - Podocyrtis (Podocyrtopsis) apeza interval subzone, new subzone

\section{Definition}

Biostratigraphic interval between the FO of Podocyrtis (Podocyrtopsis) apeza Sanfilippo and Riedel (base), and the ET from Podocyrtis (Lampterium) mitra Ehrenberg, to Podocyrtis (Lampterium) chalara Riedel and Sanfilippo (top).

\section{Occurrence at hole $1260 \mathrm{~A}$}

Base: from sample ODP 1260A-10R-5W, 55-57 cm $(83.33 \mathrm{rmcd})$ to sample ODP $1260 \mathrm{~A}-10 \mathrm{R}-3 \mathrm{~W}, 55-57 \mathrm{~cm}$ $(80.33 \mathrm{rmcd})$. Top: from sample ODP $1260 \mathrm{~A}-9 \mathrm{R}-1 \mathrm{~W}$, $55-57 \mathrm{~cm}(66.85 \mathrm{rmcd})$ to sample ODP 1260A-8R-6W, $54-56 \mathrm{~cm}(65.74 \mathrm{rmcd})$.

\section{Estimated age}

From 41.79 to $41.15 \mathrm{Ma}$ in the equatorial Atlantic (Westerhold and Röhl, 2013) and from 41.6 to 41.2 Ma in the equatorial Pacific (Kamikuri et al., 2012; revised ages in this study); middle Eocene (late Lutetian).

\section{Magnetostratigraphic calibration}

The base of the zone lies within Chron C19r and the top within Chron C19n at both the Atlantic (this study in combination with Suganuma and Ogg, 2006) and Pacific sites (Kamikuri et al., 2012; revised calibration in this study).

\section{Remarks}

The base of the subzone is characterized by the FO of Podocyrtis (P.) apeza, which is isochronous between ODP hole 1260A (41.79Ma), IODP Sites U1331, U1332, and U1333 (41.6 Ma), and IODP Site U1403 (41.94 Ma). The basal datum is approximately synchronous with a significant faunal turnover involving the FOs of Podocyrtis ( $P$.) apeza and Zealithapium mitra and the LOs of Lophocyrtis (L.?) alauda, Lithochytris ? pileata, Podocyrtis (P.) ampla, Podocyrtis (L.) fasciolata, and Zealithapium anoectum. This subzone is correlated with the upper part of planktic foraminifera zone P12 and the nannofossil zone NP16 at ODP hole 1260A.
RP14b - Sethochytris triconiscus

interval subzone, new subzone

\section{Definition}

Biostratigraphic interval between the FO of Sethochytris triconiscus Haeckel (base), and the FO of Podocyrtis (Podocyrtopsis) apeza Sanfilippo and Riedel (top).

\section{Occurrence at hole $1260 \mathrm{~A}$}

Base: from sample ODP 1260A-11R-3W, $55-57 \mathrm{~cm}$ $(89.55 \mathrm{rmcd})$ to sample ODP $1260 \mathrm{~A}-11 \mathrm{R}-2 \mathrm{~W}, 55-57 \mathrm{~cm}$ $(88.05 \mathrm{rmcd})$. Top: from sample ODP 1260A-10R-5W, $55-57 \mathrm{~cm}$ (83.33 rmcd) to sample ODP 1260A-10R-3W, $55-57 \mathrm{~cm}(80.33 \mathrm{rmcd})$.

\section{Estimated age}

From 42.08 to $41.79 \mathrm{Ma}$ in the equatorial Atlantic (Westerhold and Röhl, 2013) and 42.1 to $41.9 \mathrm{Ma}$ in the equatorial Pacific (Kamikuri et al., 2012; revised ages in this study); middle Eocene (Lutetian).

\section{Magnetostratigraphic calibration}

The new subzone falls completely in Chron C19r at both the Atlantic (this study in combination with Suganuma and Ogg, 2006) and Pacific sites (Kamikuri et al., 2012; revised calibration in this study).

\section{Remarks}

The base of the subzone is characterized by the FO of Sethochytris triconiscus, which is isochronous between ODP hole 1260A (42.08 Ma) and IODP Sites U1331, U1332, and U1333 (42.1 Ma). The basal datum is synchronous with the FO of Dictyoprora ovata at ODP hole 1260A. The Sethochytris triconiscus subzone is correlated with the planktic foraminifera zone P12 and the nannofossil zone NP16.

RP14a - Artostrobus quadriporus interval subzone, new subzone

\section{Definition}

Biostratigraphic interval between the ET from Podocyrtis (Lampterium) sinuosa Ehrenberg, to Podocyrtis (Lampterium) mitra Ehrenberg (base), and the FO of Sethochytris triconiscus Haeckel (top).

\section{Occurrence at hole 1260A}

Base: from sample ODP 1260A-13R-5W, 54-56 cm $(111.24 \mathrm{rmcd})$ to sample ODP $1260 \mathrm{~A}-13 \mathrm{R}-4 \mathrm{~W}, 55-56 \mathrm{~cm}$ (109.75 rmcd). Top: from sample ODP 1260A-11R-3W, 
$55-57 \mathrm{~cm}(89.55 \mathrm{rmcd})$ to sample ODP $1260 \mathrm{~A}-11 \mathrm{R}-2 \mathrm{~W}$, $55-57 \mathrm{~cm}(88.05 \mathrm{rmcd})$.

\section{Estimated age}

From 42.98 to $42.08 \mathrm{Ma}$ in the equatorial Atlantic (Westerhold and Röhl, 2013) and from 43.2 to $42.1 \mathrm{Ma}$ in the equatorial Pacific (Kamikuri et al., 2012; revised ages in this study); middle Eocene (Lutetian).

\section{Magnetostratigraphic calibration}

The base of the zone is located within Chron C20n and the top in Chron C19r at both the Atlantic (this study in combination with Suganuma and Ogg, 2006) and Pacific sites (Kamikuri et al., 2012; revised calibration in this study).

\section{Remarks}

The basal datum is nearly synchronous with the FO of $A r$ tostrobus quadriporus at ODP hole 1260A. This subzone is correlated with the planktic foraminifera zone P12 and the lower part of nannofossil zone NP16

RP13 - Podocyrtis (Podocyrtoges) ampla lineage zone (Riedel and Sanfilippo, 1970, 1978)

\section{Definition}

Biostratigraphic interval between the ET from Podocyrtis (Podocyrtoges) phyxis Sanfilippo and Riedel, to Podocyrtis (Podocyrtoges) ampla Ehrenberg (base), and the ET from Podocyrtis (Lampterium) sinuosa Ehrenberg, to Podocyrtis (Lampterium) mitra Ehrenberg (top).

\section{Occurrence at hole $1260 \mathrm{~A}$}

Base: from sample ODP 1260A-15R-3W, $55-57 \mathrm{~cm}$ $(128.97 \mathrm{rmcd})$ to sample ODP $1260 \mathrm{~A}-15 \mathrm{R}-2 \mathrm{~W}, 55-57 \mathrm{~cm}$ (127.47 rmcd). Top: from sample ODP 1260A-13R-5W, $54-56 \mathrm{~cm}(111.24 \mathrm{rmcd})$ to sample ODP $1260 \mathrm{~A}-13 \mathrm{R}-4 \mathrm{~W}$, $55-56 \mathrm{~cm}(109.75 \mathrm{rmcd})$.

\section{Estimated age}

From 43.67 to $42.98 \mathrm{Ma}$ in the equatorial Atlantic (Westerhold and Röhl, 2013) and from 43.9 to 43.2 Ma in the equatorial Pacific (Kamikuri et al., 2012; revised ages in this study); middle Eocene (middle Lutetian).

\section{Magnetostratigraphic calibration}

The base of this zone is located within the upper part of Chron C20r and the top in the lower part of Chron C20n at both the Atlantic (this study in combination with Suganuma and Ogg, 2006) and Pacific sites (Kamikuri et al., 2012; revised calibration in this study).

\section{Secondary bioevents}

Nine FOs (Artostrobus quadriporus, Pteropilium ? contiguum, Giraffospyris haeckelii, Siphocampe? elegans, Lithochytris ? pileata, Eucyrtidium ? picus, Lophophaena radians, Coccolarnacium periphaenoides, Lophocyrtis (L.?) barbadense) and four LOs (Podocyrtis (P.) diamesa, Thecosphaerella aff. agdaraensis, Siphocampe ? amygdala, and Podocyrtis (P.) phyxis).

\section{Remarks}

The basal datum is approximately synchronous with the LO of the planktic foraminiferal species Morozovella aragonensis, which defined the base of the zone P12. The Podocyrtis $(P$.) ampla zone corresponds to the lowermost part of planktic foraminifera zone P12 and to the uppermost part of nannofossil zone NP15 to the lowermost part of zone NP16. This zone is divided into a lower (a) and a upper (b) subzone.

RP13b - Coccolarnacium periphaenoides interval subzone, new subzone

\section{Definition}

Biostratigraphic interval between the LO of Podocyrtis (Podocyrtoges) phyxis Sanfilippo and Riedel (base), and the ET from Podocyrtis (Lampterium) sinuosa Ehrenberg, to Podocyrtis (Lampterium) mitra Ehrenberg (top).

\section{Occurrence at hole 1260A}

Base: from sample ODP 1260A-14R-7W, 55-57 cm (125.02 rmcd) to sample ODP 1260A-14R-6W, 55-57 cm (123.52 rmcd). Top: from sample ODP 1260A-13R-5W, $54-56 \mathrm{~cm}$ (111.24 rmcd) to sample ODP 1260A-13R-4W, $55-56 \mathrm{~cm}(109.75 \mathrm{rmcd})$.

\section{Estimated age}

From 43.48 to $42.98 \mathrm{Ma}$ in the equatorial Atlantic (Westerhold and Röhl, 2013) and from 43.6 to 43.2 Ma in the equatorial Pacific (Kamikuri et al., 2012; revised ages in this study); middle Eocene (middle Lutetian).

\section{Magnetostratigraphic calibration}

The subzone falls completely in Chron C20n at both the Atlantic (this study in combination with Suganuma and Ogg, 2006) and Pacific sites (Kamikuri et al., 2012; revised calibration in this study).

\section{Remarks}

This subzone approximately corresponds to the stratigraphic extension of Coccolarnacium periphaenoides at hole 1260A. The FO of the nannofossil species Nannotetrina fulgens, 
which define the base of the zone NP16, is recorded in this subzone. This subzone is correlated with the lowermost part of planktic foraminifera zone P12 and the uppermost part of microfossil zone NP15 to the lowermost part of zone NP16.

RP13a - Siphocampe ? amygdala interval subzone, new subzone

\section{Definition}

Biostratigraphic interval between the ET from Podocyrtis (Podocyrtoges) phyxis Sanfilippo and Riedel, to Podocyrtis (Podocyrtoges) ampla Ehrenberg (base), and the LO of Podocyrtis (Podocyrtoges) phyxis Sanfilippo and Riedel (top).

\section{Occurrence at hole $1260 \mathrm{~A}$}

Base: from sample ODP $1260 \mathrm{~A}-15 \mathrm{R}-3 \mathrm{~W}, \quad 55-57 \mathrm{~cm}$ $(128.97 \mathrm{rmcd})$ to sample ODP $1260 \mathrm{~A}-15 \mathrm{R}-2 \mathrm{~W}, 55-57 \mathrm{~cm}$ $(127.47 \mathrm{rmcd})$. Top: from sample ODP $1260 \mathrm{~A}-14 \mathrm{R}-7 \mathrm{~W}$, $55-57 \mathrm{~cm}(125.02 \mathrm{rmcd})$ to sample ODP $1260 \mathrm{~A}-14 \mathrm{R}-6 \mathrm{~W}$, $55-57 \mathrm{~cm}(123.52 \mathrm{rmcd})$.

\section{Estimated age}

From 43.67 to $43.48 \mathrm{Ma}$ in the equatorial Atlantic (Westerhold and Röhl, 2013) and from 43.9 to $43.6 \mathrm{Ma}$ in the equatorial Pacific (Kamikuri et al., 2012; revised ages in this study); middle Eocene (middle Lutetian).

\section{Magnetostratigraphic calibration}

The subzone falls completely in Chron C20r at both the Atlantic (this study in combination with Suganuma and Ogg, 2006) and Pacific sites (Kamikuri et al., 2012; revised calibration in this study).

\section{Remarks}

This subzone corresponds to the interval where Podocyrtis $(P$.) phyxis and its descendant Podocyrtis (P.) ampla cooccur. The artostrobiid Siphocampe ? amygdala was abundant throughout this subzone, before its sudden extinction within the lower part of the Coccolarnacium periphaenoides subzone. This subzone is correlated with the uppermost part of planktic foraminifera zone P11 to the lowermost part of zone P12 and with the nannofossil zone NP15.

\author{
RP12 - Thyrsocyrtis (Pentalocorys) triacantha \\ lineage zone (Riedel and Sanfilippo, 1970; \\ emend. Riedel and Sanfilippo, 1978)
}

\section{Definition}

Biostratigraphic interval between the FO of Eusyringium lagena (Ehrenberg) (base) and the ET from Podocyrtis (Podocyrtoges) phyxis Sanfilippo and Riedel, to Podocyrtis (Podocyrtoges) ampla Ehrenberg (top).

\section{Occurrence at hole $1260 \mathrm{~A}$}

The top of this zone is located between samples ODP 1260A$15 \mathrm{R}-3 \mathrm{~W}, 55-57 \mathrm{~cm}$ (128.97 rmcd) and ODP 1260A-15R-2W, $55-57 \mathrm{~cm}(127.47 \mathrm{rmcd})$.

\section{Estimated age}

The top of the zone is dated $43.67 \mathrm{Ma}$ in the equatorial Atlantic (Westerhold and Röhl, 2013) and 43.9 Ma in the equatorial Pacific (Kamikuri et al., 2012; revised age in this study); middle Eocene (Lutetian).

\section{Magnetostratigraphic calibration}

The top of this zone is placed within the upper part of Chron C20r at both the Atlantic (this study in combination with Suganuma and Ogg, 2006) and Pacific sites (Kamikuri et al., 2012; revised calibration in this study).

\section{Remarks}

Only the very end of the zone RP12 was found in the studied interval, and it contains no secondary bioevents. Because of the poor recovery of cores $16 \mathrm{R}$ and $17 \mathrm{R}(10.2 \%$ and $50.5 \%$, respectively), we chose to stop the sampling at $130.47 \mathrm{rmcd}$ (ODP sample 1260A-15R-4W, 55-57 cm). The end of radiolarian zone RP12 is correlated with the upper part of planktic foraminifera zone P11 and nannofossil zone NP15.

\section{Discussion}

A total of 71 radiolarian bioevents were identified in the middle Eocene of the equatorial Atlantic Ocean and calibrated to the geomagnetic polarity and astronomical timescales. Our study represents the first attempt to directly calibrate radiolarian bioevents to the astronomical timescale and to give absolute ages to middle Eocene radiolarian bioevents with an unprecedented resolution. Some species described in very early studies (i.e., Ehrenberg, 1874) are calibrated for the first time in this study. We chose to include them in our analysis in order to increase the number of well-constrained calibration points available to produce age-depth models for the 
equatorial Atlantic. Nonetheless, given the limited information available on these species, their usefulness for correlations could not be assessed here; this task requires additional biostratigraphic investigations in a broad geographic area.

Comparison of our results with the radiolarian record in the equatorial Pacific demonstrates the synchroneity of primary radiolarian bioevents that underpin the middle Eocene tropical zonal scheme by means of independent correlational techniques (i.e., paleomagnetic stratigraphy and cyclostratigraphy). These observations reinforce the robustness of previously established low-latitudinal radiolarian biozonations and are evidence of its reliability across a large oceanic area. Seven secondary bioevents are also found to be synchronous between the equatorial realm of the Atlantic and Pacific oceans, as well as three secondary bioevents between low and middle latitudes in the North Atlantic Ocean, and are thus valuable for correlations. Four of these synchronous bioevents were used to subdivide zones RP13, RP14, and RP15 into seven new subzones. The choice of bioevents that define these new subzones was motivated by the abundance of associated marker species, their ease of identification, and the overall consistency of their stratigraphic range in various low-latitude sections (Riedel and Sanfilippo, 1970; Moore, 1971; Dinkelman, 1973; Nigrini et al., 2005). Although the FO of Podocyrtis (P.) apeza, which defines the base of subzone RP14c, and the LO of Artobotrys biaurita, which defines the base of subzone RP15b, are synchronous between low and middle latitudes in the North Atlantic Ocean, the new biostratigraphic scheme is restricted to the low latitudes. As a consequence of biogeographically controlled variations in species stratigraphic range, no primary bioevents for the late middle Eocene were observed at IODP Site U1403, and the degree of synchroneity of these bioevents with the low latitudes of the Atlantic Ocean could not be tested. Moreover, Podocyrtis $(P$.) phyxis, the first occurrence of which serves as a basal datum for subzone RP13b, is also a species with tropical affinities. So far it has been reported only at some low-latitudinal sites (e.g., Riedel and Sanfilippo, 1973; Sanfilippo and Riedel, 1973; Johnson, 1974; Renz, 1984; Nigrini et al., 2005) and a single midlatitudinal site located in the South Atlantic Ocean (Souza et al., 2017).

The new biostratigraphic scheme suggested herein allows a substantial increase in the stratigraphic resolution that may be offered in the low latitudes for the middle Eocene. The mean duration of a biostratigraphic unit is about $525 \mathrm{kyr}$ for a middle Eocene biozonation based on radiolarian bioevents, while it is about $1.28 \mathrm{Ma}$ for biozonations based on planktic foraminifera (Wade et al., 2011) and $1.27 \mathrm{Ma}$ for biozonations based on nannofossils (Agnini et al., 2014). Therefore, for the period of interest, radiolaria are amongst the most accurate biostratigraphic microfossils. Future progress in astronomical dating will allow the extension of astronomical calibration of radiolarian bioevents to the entire Cenozoic era to obtain a global and consistent biochronological framework, as has already been achieved for planktic foraminifera (Wade et al., 2011). The development of such a high-resolution temporal framework for Cenozoic radiolaria will benefit a wide range of macroevolutionary studies, including the search for changes in radiolarian diversity or disparity, as well as the study of their ecological response to past climatic events.

On the other hand, two-thirds of the investigated radiolarian bioevents were found to be moderately to highly diachronous between the equatorial realm of the Atlantic and Pacific oceans, as well as three-quarters of the investigated bioevents between low and middle latitudes in the North Atlantic Ocean. In contrast with previous biostratigraphic analyses carried out in the Indo-Pacific, we did not find any asymmetrical distribution of diachronous events between first occurrences and last occurrences (Johnson and Nigrini, 1985a; Nigrini and Caulet, 1992). Hence, among radiolarian datums, first occurrences do not seem to be less reliable than last occurrences for correlations.

Diachroneity of bioevents between sedimentary sections is a common phenomenon in biostratigraphy. In addition to reasons related to the biogeographic dynamics, diachroneity may be the result of a number of different other factors, including differences in sampling intensity, differences in the quality of stratigraphic and age controls, and preservational biases, bioturbation, or errors in species identification. These factors are largely independent of radiolarian biogeography and could lead to an apparent diachronism that is not due to differences in the stratigraphic range of species between different geographic areas. Diachronous bioevents can also be subject to ecological control, as has been amply demonstrated at different scales in radiolaria (e.g., Johnson and $\mathrm{Ni}$ grini, 1985a, b; Spencer-Cervato et al., 1993, 1994). In some well-constrained cases, diachronism has been explained by particular environmental conditions, such as upwelling zones (Nigrini and Caulet, 1992), large-scale changes in the boundaries of oceanic currents (Moore et al., 1993), or the discontinuous nature of the stratigraphic range of some species due to local shifts in environmental conditions (Nigrini et al., 2005). Observed patterns of diachroneity between ODP Site 1260, IODP Site U1403, and IODP Sites U1331, 1332, and 1333 are difficult to explain in terms of ecological or paleoceanographic processes because of the complexity of unraveling radiolarian migration pathways from such a limited space coverage. Although a number of radiolarian species appear first in the equatorial Atlantic Ocean and subsequently in the equatorial Pacific, there is no convincing evidence for diachroneity resulting from interoceanic migrations.

\section{Conclusion}

This study explored the stratigraphic range of 61 middle Eocene radiolarian species from the equatorial ODP Site 1260, which preserves an expanded and well-preserved siliceous record. Taking advantage of the unique time framework provided by previous magnetostratigraphic and cy- 
clostratigraphic work carried out on the studied site, our results are placed in a very precise astronomical time frame. We refined the absolute ages of 71 radiolarian bioevents, with a significantly improved age control of equatorial Atlantic sections of middle Eocene age thus providing new calibration points for the application of age-depth models in future studies. This well-constrained temporal framework may also benefit future macroevolutionary studies on Eocene radiolaria.

Subsequently, by comparison with the equatorial Pacific record, we demonstrated the synchroneity of primary radiolarian bioevents that underpin the middle Eocene zonal scheme and thus reinforced the robustness of the tropical radiolarian biozonation. Several secondary bioevents were also found to be synchronous between the equatorial realm of the Atlantic and Pacific oceans and between low and middle latitudes in the Atlantic Ocean. These bioevents were used to subdivide zones RP13, RP14, and RP15 into seven new subzones: Siphocampe ? amygdala interval subzone (RP13a), Coccolarnacium periphaenoides interval subzone (RP13b), Artostrobus quadriporus interval subzone (RP14a), Sethochytris triconiscus interval subzone (RP14b), Podocyrtis (Podocyrtopsis) apeza interval subzone (RP14c), Artobotrys biaurita interval subzone (RP15a), and Thyrsocyrtis (Pentalocorys) krooni interval subzone (RP15b). On the other hand, numerous bioevents are shown to be highly diachronous between the two oceans, with generally older appearance and disappearance dates in the Atlantic. Although it is difficult to fully explain the observed patterns of diachroneity, recognition of age-transgressive bioevents in radiolaria could have implications for our understanding of plankton migration pathways between the Atlantic and $\mathrm{Pa}$ cific oceans.

\section{Appendix A: Taxonomic list of species dealt with in this study}

We present the list of identified species here in alphabetical order, with only a few references to give the reader the species concept used in this study.

Anthocyrtoma spp. (P1. 3, fig. 7)

Anthocyrtoma sp. Riedel and Sanfilippo, 1970, p. 524, pl. 6, figs. 2-4; Petrushevskaya and Kozlova, 1972, pl. 34, figs. 1, 2; Nigrini, 1974, pl. 1E, figs. 5-9.

Anthocyrtoma spp. Nigrini et al., 2005, p. 25, pl. P3, figs. $15,16$.

\section{Artobotrys biaurita (Ehrenberg) (P1. 1, fig. 6)}

Eucyrtidium biauritum Ehrenberg, 1874, p. 226; 1876, p. 70 , pl. 10, figs. 7,8 .

Lophocyrtis biaurita (Ehrenberg): Haeckel, 1887, p. 1411; Riedel and Sanfilippo, 1978, p. 70, pl. 6, fig. 13.
Artobotrys biaurita (Ehrenberg): Petrushevskaya and Kozlova, 1979, p. 136.

Artobotrys auriculaleporis (Clark and Campbell) (P1. 1, fig. 7)

Lophophaena (Lophophaenula) auriculaleporis Clark and Campbell, 1942: p. 76; pl. 8, figs. 20, 27-29; Blueford, 1988, p. 246, pl. 3, figs. 1-3.

Artobotrys auriculaleporis (Clark and Campbell): Petrushevskaya and Kozlova, 1979, p. 137, fig. 515.

Artophormis barbadensis (Ehrenberg) (Pl. 2, fig. 23)

Calocyclas barbadensis Ehrenberg, 1874, p. 217; 1876, p. 66, pl. 18, fig. 8; Ogane et al., 2009, pl. 96, fig. 3a-c.

Artophormis barbadensis (Ehrenberg): Riedel and Sanfilippo, 1970, p. 532, pl. 13, fig. 5.

Artostrobus quadriporus Bjørklund (Pl. 1, fig. 9)

Artostrobus quadriporus Bjørklund, 1976, p. 1125 , pl. 23, figs. 15-21; Hull, 1996, p. 137, pl. 4, fig. 12.

non Artostrobus quadriporus Lazarus and Pallant, 1989, p. 362, pl. 5, figs. $16,17$.

Coccolarnacium periphaenoides Dumitrică (Pl. 3, fig. 12)

Coccolarnacium periphaenoides Dumitrică, 1989, p. 242, pl. 10, figs. 1-4, pl. 14, figs. 2-4, 9; Dumitrică, 2020, pl. 1, figs. $1,2,5,6,10$, pl. 2, figs. 1-9, pl. 7, figs. 1,2 .

Cryptocarpium ornatum (Ehrenberg) (Pl. 3, fig. 2)

Cryptoprora ornata Ehrenberg, 1874, p. 222; 1876, p. 68 , pl. 5, fig. 8; Ogane et al., 2009, pl. 6, figs. 2ac, pl. 83, figs. 5a-6d.

Cryptocarpium ornatum (Ehrenberg): Sanfilippo and Riedel, 1992, p. 6, 36, pl. 2, figs. 18-20.

Dendrospyris fragoides Sanfilippo and Riedel (Pl. 2, fig. 21)

Dendrospyris fragoides Sanfilippo and Riedel, 1973, p. 526, pl. 15, figs 8-13, pl. 31, figs. 13, 14.

Dendrospyris golli Nishimura (Pl. 2, fig. 17)

Dendrospyris golli Nishimura, 1992, p. 330, pl. 3, figs. 1, 2, pl. 12, fig. 11. 
Dictyophimus craticula Ehrenberg (Pl. 3, fig. 6)

Dictyophimus craticula Ehrenberg, 1874, p. 223; 1876, p. 68, pl. 5, figs. 4, 5; Sanfilippo and Riedel, 1973, p. 529, pl. 19, fig. 1 (partim.); Ogane et al., 2009, pl. 21, fig. 5, pl. 36, figs. 1a-f, pl. 37, figs. $2 \mathrm{a}-4$.

Dictyopodium aff. eurylophus (Pl. 1, fig. 11)

Theoperid gen. et sp. indet. Weaver and Dinkelman, 1978, pl. 8, fig. 10.

? Dictyopodium eurylophus Ehrenberg: Funakawa et al., 2006, pl. P6, figs. 8a-10.

\section{Remarks}

This morphotype is distinguished from Dictyopodium eurylophus Ehrenberg, by having a conical or weakly bladed apical horn and a subcylindrical thorax rather than a truncate conical thorax.

Dictyopodium aff. oxylophus (Pl. 1, fig. 12)

Dictyopodium sp. aff. D. oxylophus Chen 1975, p. 460, pl. 4, figs. 1, 2.

Dictyopodium aff. oxylophus Hollis et al., 2020, pl. 9, figs. 19-21b.

\section{Remarks}

This morphotype differs from Dictyopodium oxylophus Ehrenberg, in having a thorny thorax and three short spongy legs.

\section{Dictyoprora armadillo (Ehrenberg) group}

(Pl. 1, fig. 4)

Eucyrtidium armadillo Ehrenberg, 1874, pp. 225-226; 1876, p. 70, pl. 9, fig. 10.

Theocampe armadillo (Ehrenberg) group: Riedel and Sanfilippo, 1971, p. 1601, pl. 3E, figs. 3, 5 (partim.).

Dictyoprora armadillo (Ehrenberg): Nigrini, 1977, p. 250, pl. 4, fig. 4; Funakawa et al., 2006, p. 17, pl. P2, figs. $3 a-4 b$.

Dictyoprora armadillo (Ehrenberg) group: Nigrini et al., 2005, p. 31, pl. 6, fig. 9 .

Dictyoprora ovata (Haeckel) (Pl. 1, fig. 3)

Theocorys ovata Haeckel, 1887, p. 1416, pl. 69, fig. 16.

Theocampe armadillo (Ehrenberg) group: Riedel and Sanfilippo, 1971, p. 1601, pl. 3E, figs. 4, 6 (partim.).

Dictyoprora cf. D. ovata (Haeckel): Nigrini et al., 2005, pl. P6, fig. 8.
Dictyoprora ovata (Haeckel): Funakawa et al., 2006, p. 17 , pl. P2, figs. $7 \mathrm{a}$, b.

Dictyoprora pirum (Ehrenberg) (Pl. 1, fig. 5)

Eucyrtidium pirum Ehrenberg, 1874, p. 232; 1876, p. 72, pl. 10, fig. 14 .

Theocampe pirum (Ehrenberg): Riedel and Sanfilippo, 1971, pl. 3E, figs. 10, 11.

Dictyoprora pirum (Ehrenberg): Nigrini, 1977, p. 251, pl. 4, fig. 8; Nigrini et al., 2005, p. 31, pl. P6, figs. 10, 11; Funakawa et al., 2006, p. 18, pl. P2, figs. 8-9b.

Dorcadospyris anastasis Sanfilippo in Nigrini et al. (Pl. 2, fig. 11)

Dorcadospyris anastasis Sanfilippo in Nigrini et al., 2005, p. 33, pl. P1, figs. 11, 12.

Dorcadospyris confluens (Ehrenberg) (Pl. 2, fig. 20)

Petalospyris confluens Ehrenberg, 1874, p. 246; 1876, pl. 22, fig. 5; Ogane et al., 2009, pl. 75, fig. 5a-b, pl. 77, fig. 2a-c (partim.).

Dorcadospyris confluens (Ehrenberg): Sanfilippo and Riedel, 1973, p. 528, pl. 17, figs. 6-10, pl. 33, figs. 1.

Dorcadospyris ombros Sanfilippo in Nigrini et al. (Pl. 2, fig. 19)

Dorcadospyris ombros Sanfilippo in Nigrini et al., 2005, p. 36, pl. P2, figs. 5, 6 .

\section{Entapium regulare Sanfilippo and Riedel}

(Pl. 3, fig. 13)

Entapium regulare Sanfilippo and Riedel, 1973, p. 492, pl. 1, figs. 10-19, pl. 24, figs. 1-3; Blome, 1992, p. 644, pl. 3, fig. 20.

Eucyrtidium ? picus Ehrenberg (Pl. 2, fig. 15)

Eucyrtidium picus Ehrenberg, 1874, p. 232; 1876, p. 72, pl. 11, fig. 1; Ogane et al., 2009, pl. 86, figs. 6a-g.

Eusyringium lagena (Ehrenberg) (Pl. 1, fig. 10)

Lithopera lagena Ehrenberg, 1874, p. 241; 1876, p. 78, pl. 3, fig. 4.

Eusyringium lagena (Ehrenberg): Riedel and Sanfilippo, 1970, p. 527, pl. 8, figs. 5-7; Foreman, 1973, p. 435 , pl. 11 , figs. 4,5 .

Giraffospyris haeckelii (Bütschli) (Pl. 2, fig. 18)

Stephanolithis haeckelii Bütschli, 1882, pl. 32, figs. 6a, b. 
Giraffospyris haeckelii (Bütschli): Goll, 1969, p. 334, pl. 57, figs. 5-7, text-fig. 2.

\section{Histiastrum quaternarium Ehrenberg (Pl. 3, fig. 8)}

Histiastrum quaternarium Ehrenberg, 1874, p. 237; 1876, p. 74, pl. 24, fig. 3.

Histiastrum sp. A (Pl. 3, fig. 9)

Histiastrum quadribrachiatus quadribrachiatus (Sanfilippo and Riedel): Hollis et al., 2020, pl. 3, figs. 10, 11.

\section{Remarks}

This species differs from Histiastrum quaternarium Ehrenberg by having multiple lateral spines on each arm. The morphotype observed at ODP hole 1260A corresponds well to the specimens illustrated by Hollis et al. (2020), but its assignment to Stylotrochus quadribrachiatus quadribrachiatus Sanfilippo and Riedel, seems doubtful given the number and shape of the spines, as well as the length and breadth of the arms.

\section{Lithochytris ? pileata Ehrenberg (Pl. 1, fig. 14)}

Lithochytris pileata Ehrenberg, 1874, p. 239; 1876, p. 76, pl. 5, fig. 3; Ogane et al., 2009, pl. 46, figs. 4a-5d.

Lithochytris tripodium Ehrenberg, 1874, p. 239; 1876, p. 76, pl. 4, fig. 11; Ogane et al., 2009, pl. 22, figs. 9a-c.

Gen. et sp. indet. Riedel and Sanfilippo, 1970, p. 528, pl. 9, fig. 4 .

\section{Remarks}

Included here are three-segmented theoperids with a pyramidal shell, a thick-walled, pore-less, and drop-shaped cephalis, and three short curved feet. Genus assignation is questionable because of the overall resemblance between Lithochytris ? pileata, Sethochytris ? babylonis group, and Sethochytris triconiscus. As suggested by Riedel and Sanfilippo (1970), Lithochytris ? pileata may represent an intermediate morphotype between Sethochytris ? babylonis group and Sethochytris triconiscus.

Lithochytris vespertilio Ehrenberg (Pl. 3, fig. 4)

Lithochytris vespertilio Ehrenberg, 1874, p. 239; 1876, p. 76, pl. 4, fig. 10; Riedel and Sanfilippo, 1970, p. 518, pl. 9, figs. 8, 9; Ogane et al., 2009, pl. 45, figs. 1a-3e.

\section{Lithocyclia aristotelis (Ehrenberg) group}

(Pl. 3, fig. 11)

Astromma aristotelis Ehrenberg 1847, p. 55, fig. 10; 1854 , p. 21 , pl. 36 , fig. $32 ; 1874$, p. $217 ; 1876$, p. 66 , pl. 30, figs. 3, 4 .
Astractinium aristotelis (Ehrenberg) group: Petrushevskaya and Kozlova, 1972, p. 524, pl. 16, figs. 1-5.

Lithocyclia aristotelis (Ehrenberg) group: Riedel and Sanfilippo, 1970, p. 522; Riedel and Sanfilippo, 1971, p. 1588 , pl. 3 A, figs. 4,5 .

Lophocyrtis (Apoplanius) aspera (Ehrenberg) group (Pl. 1, fig. 18)

Eucyrtidium asperum Ehrenberg, 1874, p. 226; 1876, pl. 8, fig. 15; Ogane et al., 2009, pl. 89, figs. 3a-g.

Calocyclas asperum (Ehrenberg): Petrushevskaya and Kozlova, 1972, p. 548, pl. 28, figs. 16-18.

Lophocyrtis (Apoplanius) aspera (Ehrenberg): Sanfilippo and Caulet, 1998, p. 14, pl. 3A, figs. 5-10, pl. 3B, figs. 1, 2, 5-9, pl. 6, figs. 6-8.

\section{Remarks}

Grouped under this name are all the morphotypes similar in general shape to Lophocyrtis (A.) aspera (Ehrenberg), but with slightly different inner structures. The apical spine can be partially free within the cephalis or almost fully included in the cephalis wall, as in Lophocyrtis (A.) keraspera Sanfilippo and Caulet. This delicate detail cannot always be observed because of the preservation of the specimens, their orientation in the slide, or the presence of air bubbles in the cephalis cavity.

\section{Lophocyrtis (Apoplanius) keraspera Sanfilippo and} Caulet (Pl. 1, fig. 19)

Lophocyrtis (Apoplanius) keraspera Sanfilippo and Caulet, 1998, p.14, pl. 3A, figs. 13-15, pl. 3B, figs. 1214, pl. 6, figs. 9-12; Hollis et al., 2020, pl. 15, figs. 2024.

\section{Lophocyrtis (Apoplanius) klydus Sanfilippo and Caulet (Pl. 1, fig. 20)}

Lophocyrtis (Apoplanius) klydus Sanfilippo and Caulet, 1998, p. 12-14, pl. 3A, figs. 11, 12, pl. 3B, figs. 10, 11, pl. 5, figs. 4a-5b, 8, 10, 11 .

\section{Lophocyrtis (Lophocyrtis ?) alauda (Ehrenberg) (Pl. 1, fig. 16)}

Eucyrtidium alauda Ehrenberg, 1874, p. 225; 1876, p. 70, pl. 9, fig. 4; Ogane et al., 2009, pl. 49, figs. 1a-e.

? Eucyrtidium versipellis Ehrenberg, 1874, p. 233; 1876, p. 72, pl. 11, fig. 14.

Lophocyrtis (Lophocyrtis ?) cf. semipolita: Sanfilippo and Caulet, 1998, p. 10, pl. 4, fig. 7. 


\section{Remarks}

This three-segmented theoperid is included in the genus Lophocyrtis because of its cephalic structure, which is expressed externally by a well-developed apical horn with three arches at the base (sometimes reduced to dimples, see Ehrenberg, 1876, pl. 9, fig. 4). Specimens observed at ODP hole 1260A correspond well to the one illustrated by Sanfilippo and Caulet (1998; pl. 4, fig. 10), especially with regard to the proportions of the abdominal and thoracic pores. However, given the substantial morphological variability of Lophocyrtis (L.?) semipolita sensu Sanfilippo and Caulet, it is difficult to differentiate it from Lophocyrtis (L.?) alauda (Ehrenberg), which is perhaps a senior synonym of Lophocyrtis (L.?) semipolita (Clark and Campbell).

Lophocyrtis (Lophocyrtis ?) barbadense (Ehrenberg) (Pl. 1, fig. 17)

Pterocanium barbadense Ehrenberg, 1874, p. 254; 1876, pl. 17, fig. 6 .

Lophocyrtis (Lophocyrtis?) barbadense (Ehrenberg): Sanfilippo and Caulet, 1998, p. 8, pl. 4, figs. 9, 10a, b; Funakawa et al., 2006, p. 26, pl. P8, figs. 4a-5b.

Lophophaena radians Ehrenberg (Pl. 3, fig. 1)

Lophophaena radians Ehrenberg, 1874, p. 243; 1876, p. 78, pl. 8, figs. 7-9; Funakawa et al., 2006, p. 20, pl. P3, figs. 5a-6b.

\section{Periphaena pentasteriscus (Clark and Campbell)}

(Pl. 3, fig. 10)

Heliodiscus (Heliodiscetta) pentasteriscus Clark and Campbell, 1942, p. 39, pl. 3, fig. 8; Petrushevskaya and Kozlova, 1972, p. 523, pl. 13, figs. 6, 7.

\section{Remarks}

Cortical shell lenticular, smooth, with very small and dense pores.

Petalospyris diaboliscus Ehrenberg (Pl. 2, fig. 22)

Petalospyris diaboliscus Ehrenberg, 1847, p. 55, fig. 6; Ogane et al., 2009, pl. 5, figs. 6a-c, pl. 76, 3a-c.

Petalospyris flabellum Ehrenberg (P1. 2, fig. 21)

Petalospyris flabellum Ehrenberg, 1874, p. 247; 1876, p. 80, pl. 22, fig. 7; Ogane et al., 2009, pl. 2, figs. 13a, b (partim.), pl. 5, figs. 4a, b, pl. 18, figs. 5a, b.

Phormocyrtis embolum (Ehrenberg) (Pl. 2, fig. 12)

Eucyrtidium embolum Ehrenberg, 1874, p. 228; 1876, p. 70, pl. 10, fig. 5; Johnson, 1974, p. 548, pl. 4, fig. 5 (partim.); Nigrini, 1974, p. 1068, pl. 1H, figs. 4, 5; Ogane et al., 2009, pl. 22, figs. 6a-c.
? Phormocyrtis ligulata Clark and Campbell, 1942 , p. 81, pl. 7, figs. 22, 23, 27, 28; Clark and Campbell, 1945 , p. 43, pl. 6, figs. 10, 11; Blueford, 1988, p. 246 pl. 2, figs. 7-9; Hollis et al., 2020, pl. 10, figs. 17a, b.

Podocyrtis (Lampterium) chalara Riedel and Sanfilippo (Pl. 2, fig. 4)

Podocyrtis (Lampterium) chalara Riedel and Sanfilippo, 1970, p. 535, pl. 12, figs. 2, 3; Riedel and Sanfilippo, 1978, p. 71, pl. 8, fig. 3; text-fig. 3 .

\section{Podocyrtis (Lampterium) fasciolata Nigrini} (Pl. 2, fig. 6)

Podocyrtis (Podocyrtis) ampla fasciolata Nigrini, 1974, p. 1069, pl. 1K, figs. 1, 2, pl. 4, figs. 2, 3 .

Podocyrtis (Lampterium) fasciolata Nigrini: Sanfilippo et al., 1985, p. 697, fig. 30.7.

\section{Podocyrtis (Lampterium) goetheana (Haeckel)}

(Pl. 2, fig. 5)

Cycladophora goetheana Haeckel, 1887, p. 1376, pl. 65 , fig. 5 .

Podocyrtis (Lampterium) goetheana (Haeckel): Riedel and Sanfilippo, 1970, p. 535; Nigrini et al., 2005, p. 45, pl. P5, figs. 11, 12.

\section{Podocyrtis (Lampterium) mitra Ehrenberg} (P1. 2, fig. 2)

Podocyrtis mitra Ehrenberg, 1854, p. 21, pl. 36, fig. 20; 1874 , p. 251 ; 1876 , p. 82 , pl. 15, fig. 4.

Podocyrtis (Lampterium) mitra Ehrenberg: Riedel and Sanfilippo, 1970, p. 534, pl. 11, figs. 5-6; Riedel and Sanfilippo, 1978, pl. 8, fig. 7; Sanfilippo and Blome, 2001, p. 215, figs. 10a, b.

\section{Podocyrtis (Lampterium) sinuosa Ehrenberg (Pl. 2, fig. 1)}

Podocyrtis sinuosa Ehrenberg, 1874, p. 253; 1876 , p. 82 , pl. 15 , fig. 5 .

Podocyrtis (Lampterium) sinuosa Ehrenberg: Riedel and Sanfilippo, 1970, p. 534, pl. 11, figs. 3, 4.

Podocyrtis (Lampterium) trachodes Riedel and Sanfilippo (Pl. 2, fig. 3)

Podocyrtis (Lampterium) trachodes Riedel and Sanfilippo, 1970, p. 535, pl. 11, fig. 7; pl. 12, fig. 1; Sanfilippo et al., 1985, p. 699, fig. 30.14; Sanfilippo and Blome; 2001, p. 215, fig. 10c. 


\section{Podocyrtis (Podocyrtoges) ampla Ehrenberg}

(P1. 2, fig. 9)

Podocyrtis ? ampla Ehrenberg, 1874, p. 248; 1876, p. 80 , pl. 16, fig. 7 .

Podocyrtis (Podocyrtis) ampla Ehrenberg: Riedel and Sanfilippo, 1970, p. 533, pl. 12, figs. 7, 8.

Podocyrtis (Podocyrtoges) ampla Ehrenberg: Sanfilippo and Riedel, 1992, p. 14, pl. 5, fig. 4.

\section{Podocyrtis (Podocyrtoges) diamesa Riedel and Sanfil- ippo (Pl. 2, fig. 7)}

Podocyrtis (Podocyrtis) diamesa Riedel and Sanfilippo, 1970, p. 533, pl. 12, fig. 4 (partim.); Sanfilippo and Riedel, 1973, p. 531, pl. 20, figs. 9, 10, pl. 35, figs. 10, 11.

Podocyrtis (Podocyrtoges) diamesa Sanfilippo and Riedel, 1992, p. 14; Nigrini et al., 2005, p. 46, pl. P5, fig. 10 .

\section{Podocyrtis (Podocyrtoges) phyxis Sanfilippo and Riedel (Pl. 2, fig. 8)}

Podocyrtis (Podocyrtis) diamesa Riedel and Sanfilippo, 1970, p. 533, pl. 12, fig. 6 (partim.).

Podocyrtis (Podocyrtis) phyxis Sanfilippo and Riedel, 1973, p. 531.

Podocyrtis (Podocyrtoges) phyxis Sanfilippo and Riedel: Sanfilippo and Riedel, 1992, p. 14.

\section{Podocyrtis (Podocyrtopsis) apeza Sanfilippo and}

Riedel (Pl. 2, fig. 10)

Podocyrtis (Podocyrtopsis) apeza Sanfilippo and Riedel, 1992, p. 14, pl. 3, figs. 13-15; Moore and Kamikuri, 2012, p. 10, pl. P7, fig. 7.

Pteropilium aff. contiguum (Pl. 1, fig. 24)

Pteropilium ? sp. aff. Pterocanium contiguum group Petrushevskaya and Kozlova, 1972, p. 553, pl. 29, figs. $8-10$.

Pteropilium aff. contiguum Hollis et al., 2020, pl. 14, figs. 16, 17.

\section{Sethochytris ? babylonis (Clark and Campbell) group} (Pl. 1, fig. 13)

Dictyophimus (Dictyophimium) babylonis Clark and Campbell, 1942, p. 67, pl. 9, figs. 32, 36.

Sethochytris babylonis (Clark and Campbell) group: Riedel and Sanfilippo, 1970, p. 528, pl. 9, figs. 1-3.
Sethochytris triconiscus Haeckel (Pl. 1, fig. 15)

Sethochytris triconiscus Haeckel, 1887, p. 1239, pl. 57, fig. 13; Riedel and Sanfilippo, 1970, p. 528, pl. 9, figs. 6.

Gen. et sp. indet. Riedel and Sanfilippo, 1970, pl. 9, figs. 5.

Siphocampe ? amygdala (Shilov) (P1. 1, fig. 1)

Theoperid gen. et sp. indet. Johnson, 1974, pl. 3, fig. 12.

Siphocampe elizabethae (Clark and Campbell): Nigrini, 1977, p. 256, pl. 3, fig. 6.

Archaeodictyomitra? sp. Takemura, 1992, p. 744, pl. 3 , fig. 1, 2.

Dictyomitra amygdala Shilov, 1995, p. 126, pl. 1, fig. 4-6b.

Dictyoprora ? amygdala (Shilov): Suzuki et al., 2009, p. 263 , pl. 18 , fig. 3 .

Siphocampe ? amygdala (Shilov): Hollis et al., 2020, pl. 8, figs. 11, 12 .

Siphocampe ? elegans (Ehrenberg) (P1. 1, fig. 2)

Eucyrtidium elegans Ehrenberg, 1854, p. 21, pl. 36, fig. $17 ; 1874$, p. 228; 1876, pl. 11, fig. 12; Haeckel, 1862, p. 327; Ogane et al., 2009, pl. 6, figs. 11a, b.

Eucyrtidium pauperum Ehrenberg, 1874, p. 231; 1876, p. 72, pl. 11, fig. 13; Ogane et al., 2009, pl. 82, figs. $7 \mathrm{a}-\mathrm{c}$.

Thecosphaerella aff. agdaraensis (Mamedov) (P1. 3, fig. 5)

? Sphaerostylus agdaraensis Mamedov, 1969, p. 96, pl. 2, figs. 1,2

Thecosphaerella sp. cf. T. agdaraensis (Mamedov): Sanfilippo and Riedel, 1973, p. 521, pl. 2, figs. 7-9, pl. 25 , fig. 15 .

Theocorys anapographa Riedel and Sanfilippo var. A (P1. 1, fig. 8)

Theocorys anapographa Riedel and Sanfilippo var. A: Sanfilippo and Blome, 2001, p. 219, fig. 11m, n; Hollis et al., 2020, pl. 11, figs. 6a, b.

Theocotylissa ficus (Ehrenberg) (Pl. 3, fig. 3)

Eucyrtidium ficus Ehrenberg, 1874, p. 228; 1876, p. 70, pl. 11, fig. 19.

Theocotyle ? ficus (Ehrenberg): Riedel and Sanfilippo, 1970, p. 525, pl. 7, figs. 3-5. 
Theocotyle (Theocotylissa) ficus (Ehrenberg): Foreman, 1973, p. 441, pl. 4, figs. 16-20.

Theocotylissa ficus (Ehrenberg): Sanfilippo and Riedel, 1982, p. 180, pl. 2, figs. 19, 20, text-fig. 1.

Theocyrtis scolopax (Ehrenberg) (Pl. 1, fig. 25)

Eucyrtidium scolopax Ehrenberg, 1874, p. 232; 1876, p. 72, pl. 9, fig. 5; Ogane et al., 2009, pl. 58, figs. 3a-f.

Theocyrtis scolopax (Ehrenberg): Popova et al., 2002, p. 50 , fig. $14 \mathrm{G}$.

Thyrsocyrtis (Pentalacorys) krooni Sanfilippo and Moore (Pl. 2, fig. 14)

Thyrsocyrtis tetracantha (Ehrenberg): Riedel and Sanfilippo, 1978, p. 81, pl. 10, fig. 9 (partim.).

Thyrsocyrtis (Pentalacorys) tetracantha (Ehrenberg): Sanfilippo and Riedel, 1982, p. 176 (partim.), pl. 1, fig. 11.

Thyrsocyrtis (Pentalacorys) krooni Sanfilippo and Blome, 2001, p. 207, figs. 7a-e; Moore and Kamikuri, 2012, p. 11, pl. P8, figs. $7,8$.

\section{Thyrsocyrtis (Pentalacorys) tetracantha (Ehrenberg)} (Pl. 2, fig. 13)

Podocyrtis tetracantha Ehrenberg, 1874, p. 254; 1876, p. 82 , pl. 13 , fig. 2 .

Thyrsocyrtis tetracantha (Ehrenberg): Riedel and Sanfilippo, 1978, p. 81 (partim.), pl. 10, fig. 8 .

Thyrsocyrtis (Pentalacorys) tetracantha (Ehrenberg): Sanfilippo and Riedel, 1982, p. 176, pl. 1, fig. 12, pl. 3, fig. 10, text-fig. 1 (partim.).

\section{Zealithapium anoectum (Riedel and Sanfilippo)}

(Pl. 1, fig. 22)

Lithapium ? anoectum Riedel and Sanfilippo, 1970, p. 520, pl. 4, figs. 4,5 .

Lithapium anoectum Sanfilippo and Riedel, 1973, p. 516, pl. 24, figs. 6,7 .

Zealithapium anoectum (Ehrenberg): O'Connor, 1999, p. 5.

Zealithapium mitra (Ehrenberg) (Pl. 1, fig. 23)

Cornutella mitra Ehrenberg, 1874, p. 221; 1876, p. 68, pl. 2, figs. 8 .

Lithapium ? mitra (Ehrenberg): Riedel and Sanfilippo, 1970, p. 520, pl. 4, figs. 6, 7.
Lithapium mitra (Ehrenberg): Sanfilippo and Riedel, 1973, p. 516.

Zealithapium mitra (Ehrenberg): O'Connor, 1999, p. 5.

Zealithapium plegmacantha (Riedel and Sanfilippo) (Pl. 1, fig. 21)

Lithapium ? plegmacantha Riedel and Sanfilippo, 1970, p. 520, pl. 4, figs. 2-3.

Lithapium plegmacantha Riedel and Sanfilippo: Sanfilippo and Riedel, 1973, p. 516, pl. 4, figs. 8, 9.

Zealithapium plegmacantha (Ehrenberg): O'Connor, 1999, p. 5.

Data availability. Biostratigraphic data generated in this study are available in Supplement 1. Illustrated specimens are housed in the paleontological collection of the University of Lille, Villeneuved'Ascq, France.

Supplement. The supplement related to this article is available online at: https://doi.org/10.5194/jm-41-1-2022-supplement.

Author contributions. TD designed and directed the project. MM was responsible for the data acquisition, analysis, and drawing of figures. The interpretation of data and discussion of results were conducted by both authors. MM wrote the paper, in consultation with TD.

Competing interests. The contact author has declared that neither he nor his co-author has any competing interests.

Disclaimer. Publisher's note: Copernicus Publications remains neutral with regard to jurisdictional claims in published maps and institutional affiliations.

Acknowledgements. We thank Christopher J. Hollis and an anonymous reviewer for their constructive remarks. Thanks also to the Ocean Drilling Program (ODP) for supplying the samples used in this study. We are indebted to TMS for covering the publication cost of this paper.

Review statement. This paper was edited by Kirsty Edgar and reviewed by Chris Hollis and one anonymous referee.

\section{References}

Agnini, C., Fornaciari, E., Raffi, I., Catanzariti, R., Pälike, H., Backman, J., and Rio, D.: Biozonation and biochronology of Paleogene calcareous nannofossils from low and middle latitudes, 
Newsl. Stratigr., 47, 131-181, https://doi.org/10.1127/00780421/2014/0042, 2014.

Bjørklund, K. R.: Radiolaria from the Norwegian Sea, Leg 38 of the Deep Sea Drilling Project, in: Initial Reports of the Deep Sea Drilling Project, 38, edited by: Talwani, M., Udintsev, G., Bjørklund, K., Caston, V. N. D., Faas, R. W., Kharin, G. N., Morris, D. A., Müller, C., Nilsen, T. H., van Hinte, J., Warnke, D. A., and White, S. M., U.S. Govt. Print. Office, Washington, DC, USA, 1101-1168, https://doi.org/10.2973/dsdp.proc.38.131.1976, 1976.

Blome, C. D.: Radiolarians from Leg 122, Exmouth and Wombat Plateau, Indian Ocean, in: Proceedings of the Ocean Drilling Program, Scientific Results, 122, edited by: Haq, B. U., von Rad, U., O'Conneü, S., Bent, A., Blome, C. D., Borella, P. E., Boyd, R., Bralower, T. J., Brenner, W. W., de Carlo, E. H., Dumont, T., Meville, E., Qalbrun, B., Golovchenko, X., Görür, M., Ito, M., Lorenzo, J. M., Meyers, P. A., Moxon, I., O’Brien, D. K., Oda, M., Sarti, M., Siesser, W. Q., Snowdon, L. R., Tang, C., Wilkens, R. H., Williamson, P., and Wonders, A. H., Ocean Drill. Program, College Station, TX, USA, 633-652, https://doi.org/10.2973/odp.proc.sr.122.165.1992, 1992.

Blueford, J.: Radiolarian biostratigraphy of siliceous Eocene deposits in central California, Micropaleontology, 34, 236-258, https://doi.org/10.2307/1485754, 1988.

Boulila, S., Vahlenkamp, M., De Vleeschouwer, D., Laskar, J., Yamamoto, Y., Pälike, H., Kirtland Turner, S., Sexton, P. F., Westerhold, T., and Röhl, U.: Towards a robust and consistent middle Eocene astronomical timescale, Earth Planet. Sc. Lett., 486, 94107, https://doi.org/10.1016/j.eps1.2018.01.003, 2018.

Bütschli, O.: Beiträge zur Kenntnis der Radiolarienskelette, insbesondere der Cyrtida, Zeitschrift für Wissenschaftliche Zoologie, 36, 485-540, 1882.

Chen, P.-H.: Antarctic Radiolaria, in: Initial Reports of the Deep Sea Drilling Project, 28, edited by: Hayes, D. E., Frakes, L. A., Barrett, P. J., Burns, D. A., Chen, P.-H., Ford, A. B., Kaneps, A. G., Kemp, E. M., McCollum, D. W., Piper, D. J. W., Wall, R. E., and Webb, P. N., U.S. Govt. Print. Office, Washington, DC, USA, 437-513, https://doi.org/10.2973/dsdp.proc.28.111.1975, 1975.

Clark, B. L. and Campbell, A. S.: Eocene radiolarian faunas from the Monte Diablo area, California, Geological Society of America, Special Papers 39, Waverly Press, Baltimore, MD, USA, 112 pp., https://doi.org/10.1130/SPE39, 1942.

Clark, B. L. and Campbell, A. S.: Radiolaria from the Kreyenhagen Formation near Los Banos, California, Geological Society of America, Memoir. 10, Waverly Press, Baltimore, MD, USA, 66 pp., https://doi.org/10.1130/MEM10, 1945.

Danelian, T., Le Callonec, L., Erbacher, J., Mosher, D., Malone, M., Berti, D., Bice, K., Bostock, H., Brumsack, H.-J, Forster, A., Heidersdorf, F., Henderiks, J., Janecek, T., Junium, C., Macleod, K., Meyers, P., Mutterlose J., Nishi, H., Norris, R., Ogg, J., O'Regan, M., Rea, B., Sexton, P., Sturt, H., Suganuma, Y., Thurow, J., Wilson, P., Wise, S., and Glatz, C.: Preliminary results on Cretaceous-Tertiary tropical Atlantic pelagic sedimentation (Demerara Rise, ODP Leg 207), C.R. Geosci., 337, 609616, https://doi.org/10.1016/j.crte.2005.01.011, 2005.

Danelian, T., Saint Martin, S., and Blanc-Valleron, M.-M.: Middle Eocene radiolarian and diatom accumulation in the equatorial Atlantic (Demerara Rise, ODP Leg 207): Possible links with climatic and palaeoceanographic changes, C.R. Palevol., 6, 103114, https://doi.org/10.1016/j.crpv.2006.08.002, 2007.

De Wever, P., Dumitrică, P., Caulet, J.-P., Nigrini, C., and Caridroit, M.: Radiolarians in the sedimentary record, Gordon and Breach Science Publishers, Amsterdam, the Netherlands, 533 pp., 2001.

Dinkelman, M. G.: Radiolarian stratigraphy: Leg 16, Deep Sea Drilling Project, in: Initial Reports of the Deep Sea Drilling Project, 16, edited by: van Andel, T. H., Heath, G. R., Bennett, R. H., Bukry, J. D., Charleston, S., Cronan, D. S., Dinkelman, M. G., Kaneps, A. G., Rodolfo, K. S., and Yeats, R. S., U.S. Govt. Print. Office, Washington, DC, USA, 747-813, https://doi.org/10.2973/dsdp.proc.16.128.1973, 1973.

Dumitrică, P.: Internal skeletal structures of the superfamily Pyloniacea (Radiolaria), a basis of a new systematics, Revista española de Micropaleontologia, 21, 207-264, 1989.

Dumitrică, P.: Some new or newly interpreted Cenozoic larnacillid radiolarian taxa, Rev. Micropaleontol., 66, 100405, https://doi.org/10.1016/j.revmic.2019.100405, 2020.

Ehrenberg, C. G.: Über die mikroskopischen kieselschaligen Polycystinen als mächtige Gebirgsmasse von Barbados und über das Verhältniss der aus mehr als 300 neuen Arten bestehenden ganz eigenthümlichen Formengruppe jener Felsmasse zu den jetzt lebenden Thieren und zur Kreidebildung. Eine neue Anregung zur Erforschung des Erdlebens, K. Preuss. Akad. Wiss. Ber., Jahre 1847, 40-60, 1847.

Ehrenberg, C. G.: Mikrogeologie: das Erden und Felsen schaffende Wirken des unsichtbar kleinen selbstständigen Lebens auf der Erde, Leopold Voss, Leipzig, Germany, 374 pp., https://doi.org/10.5962/bhl.title.118752, 1854.

Ehrenberg, C. G.: Grössere Felsproben des Polycystinen-Mergels von Barbados mit weiteren Erläuterungen, K. Preuss. Akad. Wiss., Monatsb., Jahre 1873, 213-263, 1874.

Ehrenberg, C. G.: Fortsetzung der mikrogeologischen Studien als Gesammt-Übersicht der mikroskopischen Paläontologie gleichartig analysirter Gebirgsarten der Erde, mit specieller Rücksicht auf den Polycystinen-Mergel von Barbados, K. Preuss. Akad. Wiss. Berlin, Abh., Jahre 1875, 1-226, 1876.

Foreman, H. P.: Radiolaria of Leg 10 with systematics and ranges for the families Amphipyndacidae, Artostrobiidae and Theoperidae, in: Initial Reports of the Deep Sea Drilling Project, 10, edited by: Worzel, J. L., Bryant, W., Beall Jr., A. O., Capo, R., Dickinson, K., Foreman, H. P., Laury, R., McNeely, B. W., and Smith, L. A., U.S. Govt. Print. Office, Washington, DC, USA, 407-474, https://doi.org/10.2973/dsdp.proc.10.118.1973, 1973.

Funakawa, S., Nishi, H., Moore, T. C., and Nigrini, C. A.: Data report: Late Eocene-early Oligocene radiolarians, ODP Leg 199 Holes 1218A, 1219A, and 1220A, central Pacific, in: Proc. ODP, Sci. Results 199, edited by: Wilson, P. A., Lyle, M., and Firth, J. V., Ocean Drill. Program, College Station, TX, USA, 1-74, https://doi.org/10.2973/odp.proc.sr.199.216.2006, 2006.

Goll, R. M.: Classification and phylogeny of Cenozoic Trissocyclidae (Radiolaria) in the Pacific and Caribbean basins, Part II, J. Paleontol., 43, 322-339, 1969.

Haeckel, E.: Die Radiolarien (Rhizopoda Radiaria). Eine Monographie, Reimer, Berlin, xiv + 572 pp., https://doi.org/10.5962/bhl.title.10155, 1862.

Haeckel, E.: Report on the Radiolaria collected by H.M.S. Challenger during the years 1873-1876, Report on the Scientific Results of the Voyage of the H.M.S, Challenger, 
Zoology, 18, Eyre and Spottiswoode, London, 1803 pp., https://doi.org/10.5962/bhl.title.6513, 1887.

Hollis, C. J.: Latest Cretaceous to Late Paleocene radiolarian biostratigraphy: A new zonation from the New Zealand region, Mar. Micropaleontol., 21, 295-327, https://doi.org/10.1016/03778398(93)90024-R, 1993.

Hollis, C. J., Pascher, K. M., Sanfilippo, A., Nishimura, A., Kamikuri, S.-I., and Shepherd, C. L.: An Austral radiolarian biozonation for the Paleogene, Stratigraphy, 17, 213-278, https://doi.org/10.29041/strat.17.4.213-278, 2020.

Hull, D. M.: Paleoceanography and biostratigraphy of Paleogene radiolarians from the Norwegian-Greenland Sea, in: Proceedings of the Ocean Drilling Program, Scientific Results, 151, edited by: Thiede, J., Myhre, A. M., Firth, J. V., Johnson, G. L., and Ruddiman, W. F., Ocean Drill. Program, College Station, TX, USA, 125-152, https://doi.org/10.2973/odp.proc.sr.151.103.1996, 1996.

Johnson, D. A.: Radiolaria from the Eastern Indian Ocean, DSDP Leg 22, in: Initial Reports of the Deep Sea Drilling Project, 22, edited by: von der Borch, C. C., Sclater, J. G., Gartner, Jr., S., Hekinian, R., Johnson, D. A., McGowran, B., Pimm, A. C., Thompson, R. W., Veevers, J. J., and Waterman, L. S., U.S. Govt. Print. Office, Washington, DC, USA, 521-575, https://doi.org/10.2973/dsdp.proc.22.126.1974, 1974.

Johnson, D. A. and Nigrini, C. A.: Time-transgressive late Cenozoic radiolarian events of the equatorial Indo-Pacific, Science, 20, 538-540, https://doi.org/10.1126/science.230.4725.538, 1985a.

Johnson, D. A. and Nigrini, C. A.: Synchronous and timetransgressive Neogene radiolarian datum levels in the equatorial Indian and Pacific Oceans, Mar. Micropaleontol., 9, 489-524, https://doi.org/10.1016/0377-8398(85)90015-5, 1985b.

Kamikuri, S.-I., Moore, T. C., Ogane, K., Suzuki, N., Pälike, H., and Nishi, H.: Early Eocene to early Miocene radiolarian biostratigraphy for the low-latitude Pacific Ocean, Stratigraphy, 9, 77-108, 2012.

Lazarus, D.: A brief review of radiolarian research, Palaontol. Z., 79, 183-200, https://doi.org/10.1007/BF03021761, 2005.

Lazarus, D. and Pallant, A.: Oligocene and Neogene radiolarians from the Labrador Sea, ODP LEG 105, in: Proceedings of the Ocean Drilling Program, Scientific Results, 105, edited by: Srivastava, S. P., Arthur, M., Clement, B., Aksu, A., Baldauf, J., Bohrmann, G., Busch, W., Cederberg, T., Cremer, M., Dadey, K., De Vernal, A., Firth, J., Hall, F., Head, M., Hiscott, R., Jarrard, R., Kaminski, M., Lazarus, D., Monjanel, A.-L., Nielson, O. B., Stein, R., Thiebault, F., Zachos, J., and Zimmerman, H., Ocean Drill. Program, College Station, TX, USA, 349-380, https://doi.org/10.2973/odp.proc.sr.105.125.1989, 1989.

Lourens, L. J., Hilgen, F. J., Shackleton, N. J., Laskar, J., and Wilson, D. S.: The Neogene Period, in: The Geologic Time Scale, Chapter 21, edited by: Gradstein, F. M., Ogg, J. G., Smith, A. G., Cambridge University Press, Cambridge, UK, 409-440, https://doi.org/10.1017/CBO9780511536045, 2004.

Mamedov, N. A.: Novye predstaviteli eotsenovykh radiolyarii Azerbaidzhana, in: Iskopaemye i Sovremennye Radiolyarii: Materialy vtorogo vsesoyuznogo seminara po radiolariyam, Vyalov, O. S., Izdatelstvo Lvovskogo Universiteta, Lvov, Ukraine, 94-101, 1969.

Moore Jr., T. C.: Radiolaria, in: Initial Reports of the Deep Sea Drilling Project, 8, edited by: Tracey Jr., J. I., Sutton, G.
H., Nesteroff, W. D., Galehouse, J., Von der Borch, C. C., Moore, T., Lipps, J., Haq, U. Z. B. U., and Beckmann, J. P., U.S. Govt. Print. Office, Washington, DC, USA, 727-775, https://doi.org/10.2973/dsdp.proc.8.112.1971, 1971.

Moore Jr., T. C. and Kamikuri, S.-I.: Data report: radiolarian stratigraphy across the Eocene/Oligocene boundary in the equatorial Pacific, Sites 1218, U1333, and U1334, in: Proceedings of the Integrated Ocean Drilling Program, 320/321, edited by: Pälike, H., Lyle, M., Nishi, H., Raffi, I., Gamage, K., Klaus, A., and the Expedition 320/321 Scientists, Ocean Drill. Program, College Station, TX, USA, 1-37, https://doi.org/10.2204/iodp.proc.320321.204.2012, 2012.

Moore Jr., T. C., Skackleton, N. J., and Pisias, N. G.: Paleoceanography and the diachrony of radiolarian events in the eastern equatorial Pacific, Paleoceanography, 8, 567-586, https://doi.org/10.1029/93pa01328, 1993.

Nigrini, C.: Cenozoic Radiolaria from the Arabian Sea, DSDP Leg 23, in: Initial Reports of the Deep Sea Drilling Project, 23, edited by: Whitmarsh, R. B., Weser, O. E., Ali, S., Boudreaux, J. E., Fleisher, R. L., Jipa, D., Kidd, R. B., Mallik, T. K., Matter, A., Nigrini, C., Siddiquie, H. N., and Stoffers, P., U.S. Govt. Print. Office, Washington, DC, USA, 1051-1121, https://doi.org/10.2973/dsdp.proc.26.233.1974, 1974.

Nigrini, C.: Equatorial Cenozoic Artostrobiidae (Radiolaria), Micropaleontology, 23, 241-269, https://doi.org/10.2307/1485215, 1977.

Nigrini, C. and Caulet, J. P.: Late Neogene radiolarian assemblages characteristic of Indo-Pacific areas of upwelling, Micropaleontology, 38, 139-164, https://doi.org/10.2307/1485992, 1992.

Nigrini, C., Sanfilippo, A., and Moore Jr., T. J.: Cenozoic radiolarian biostratigraphy: a magnetobiostratigraphic chronology of Cenozoic sequences from ODP Sites 1218, 1219, and 1220, equatorial Pacific, in: Proceedings of the Ocean Drilling Program, Scientific Results, 199, edited by: Wilson, P. A., Lyle, M., and Firth, J. V., Ocean Drill. Program, College Station, TX, USA, 1-76, https://doi.org/10.2973/odp.proc.sr.199.225.2006, 2005.

Nishimura, A.: Cenozoic Radiolaria in the western North Atlantic, Site 603, Leg 93 of the Deep Sea Drilling Project, in: Initial Reports of the Deep Sea Drilling Project, 92 (part 2), edited by: van Hinte, J. E., Wise Jr., S. W., Biart, B. N. M., Covington, J. M., Dunn, D. A., Haggerty, J. A., Johns, M. W., Meyers, P. A., Moullade, M. R., Muza, J. P., Ogg, J. G., Okamura, M., Sarti, M., and von Rad, U., U.S. Govt. Print. Office, Washington, DC, USA, 713-737, https://doi.org/10.2973/dsdp.proc.93.120.1987, 1987.

Nishimura, A.: Paleocene radiolarian biostratigraphy in the northwest Atlantic at Site 384, Leg 43, of the Deep Sea Drilling Project, Micropaleontology, 38, 317-362, https://doi.org/10.2307/1485764, 1992.

O'Connor, B. M.: Radiolaria from the Late Eocene Oamaru Diatomite, South Island, New Zealand, Micropaleontology, 45, 155, https://doi.org/10.2307/1486201, 1999.

Ogane, K., Suzuki, N., Aita, Y., Sakai, T., Lazarus, D., and Tanimura, Y.: Ehrenberg's radiolarian collections from Barbados, in: Joint Haeckel and Ehrenberg Project: Reexamination of the Haeckel and Ehrenberg Microfossil Collection as a historical and scientific legacy, edited by: Tanimura, Y. and Aita, Y., National Museum of Nature and Science Monographs 40, Tokyo, Japan, 97-106, ISBN 978-4-87803-029-1, 2009. 
Petrushevskaya, M. G. and Kozlova, G. E.: Radiolaria: Leg 14, Deep Sea Drilling Project, in: Initial Reports of the Deep Sea Drilling Project, 14, edited by: Hayes, D. E., Pimm, A. C., Beckmann, J. P., Benson, W. E., Berger, W. H., Roth, P. H., Supko, P. R., and von Rad, U., U.S. Govt. Print. Office, Washington, DC, USA, 495-648, https://doi.org/10.2973/dsdp.proc.14.116.1972, 1972.

Petrushevskaya, M. G. and Kozlova, G. E.: Opisanie rodov i vidov Radiolyarii, Issledovaniya Fauny Morei, Istoziya mikroplanktona norvezhskogo morya (po materialom glubokovodnogo bureniya), 23, 86-157, 1979.

Popova, I. M., Baumgartner, P. O., Guex, J., Tochilina, S. V., and Glezer, Z. I.: Radiolarian biostratigraphy of Palaeogene deposits of the Russian Platform (Voronesh Anticline), Geodiversitas, 24, 7-59, 2002.

Renaudie, J., Danelian, T., Saint-Martin, S., Le Callonec, L., and Tribovillard, N.: Siliceous phytoplankton response to a Middle Eocene warming event recorded in the tropical Atlantic (Demerara Rise, ODP Site 1260A), Palaeogeogr. Palaeoclimatol. Palaeoecol., 286, 121-134, https://doi.org/10.1016/j.palaeo.2009.12.004, 2010.

Renz, G. W.: Cenozoic radiolarians from the Barbados Ridge, Lesser Antilles subduction complex, Deep Sea Drilling Project Leg 78A, in: Initial Reports of the Deep Sea Drilling Project, 78A, edited by: Biju-Duval, B., Moore, J. C., Bergen, J. A., Blackinton, G., Claypool, G. E., Cowan, D. S., Davis, D., Guerra, R. T., Hemleben, C. H. J., Marlow, M. S., Pudsey, C., Renz, G. W., Tardy, M., Wilson, D. S., and Wright, A. W., U.S. Govt. Print. Office, Washington, DC, USA, 447-462, https://doi.org/10.2973/dsdp.proc.78A.121.1984, 1984.

Riedel, W. R.: Radiolaria: a preliminary stratigraphy, in: Reports of the Swedish Deep-Sea Expedition, 1947-1948, edited by: Petterson, H., Elanders Boktryckeri Aktiebolag, Göteborg, Sweden, 6, 59-96, 1957.

Riedel, W. R. and Sanfilippo, A.: Radiolaria, Leg 4, Deep Sea Drilling Project, in: Initial Reports of the Deep Sea Drilling Project, 4, edited by: Bader, R. G., Gerard, R. D., Benson, W. E., Bolli, H. M., Hay, W. W., Rothwell, Jr., T., Ruef, M. H., Riedel, W. R., and Sayles, F. L., U.S. Govt. Print. Office, Washington, DC, USA, 503-575, https://doi.org/10.2973/dsdp.proc.4.124.1970, 1970.

Riedel, W. R. and Sanfilippo, A.: Cenozoic Radiolaria from the western equatorial Pacific, Leg 7, in: Initial Reports of the Deep Sea Drilling Project, 7, edited by: Winterer, E. L., Riedel, W. R., Brönnimann, P., Gealy, E. L., Heath, G. R., Kroenke, L., Martini, E., Moberly Jr., R., Resig, J., and Worsley, T., U.S. Govt. Print. Office, Washington, DC, USA, 1529-1672, https://doi.org/10.2973/dsdp.proc.7.132.1971, 1971.

Riedel, W. R. and Sanfilippo, A.: Cenozoic Radiolaria from the Caribbean, Deep Sea Drilling Project, Leg 15, in: Initial Reports of the Deep Sea Drilling Project, 15, edited by: Edgar, N. T., Saunders, J. B., Bolli, H. M., Boyce, R. E., Broecker, W. S., Donnelly, T. W., Gieskes, J. M., Hay, W. W., Horowitz, R. M., Maurrasse, F., Nieto, H. P., Prell, W., Silva, I. P., Riedel, W. R., Scheidermann, N., and Waterman, L. S., U.S. Govt. Print. Office, Washington, DC, USA, 705-751, https://doi.org/10.2973/dsdp.proc.15.117.1973, 1973.
Riedel, W. R. and Sanfilippo, A.: Stratigraphy and evolution of equatorial Cenozoic radiolarians, Micropaleontology, 24, 61-96, https://doi.org/10.2307/1485420, 1978.

Sanfilippo, A. and Blome, C. D.: Biostratigraphic implications of mid-latitude Palaeocene-Eocene radiolarian faunas from Hole 1051A, ODP Leg 171B, Blake Nose, western North Atlantic, in: Western North Atlantic Palaeogene and Cretaceous Palaeoceanography, edited by: Kroon, D., Norris, R. D., Klaus, A., Geol. Soc. Spec. Publ., 183, 185-224, https://doi.org/10.1144/GSL.SP.2001.183.01.10, 2001.

Sanfilippo, A. and Caulet, J.-P.: Taxonomy and evolution of Paleogene Antarctic and tropical Lophocyrtid radiolarians, Micropaleontology, 44, 1-43, https://doi.org/10.2307/1486083, 1998.

Sanfilippo, A. and Nigrini, C.: Code numbers for Cenozoic low latitude radiolarian biostratigraphic zones and GPTS conversion tables, Mar. Micropaleontol., 33, 109-156, https://doi.org/10.1016/S0377-8398(97)00030-3, 1998.

Sanfilippo, A. and Riedel, W. R.: Cenozoic Radiolaria (exclusive of theoperids, artostrobiids and amphipyndacids) from the Gulf of Mexico, DSDP Leg 10, in: Initial Reports of the Deep Sea Drilling Project, 10, edited by: Worzel, J. L., Bryant, W., Beall Jr., A. O., Capo, R., Dickinson, K., Foreman, H. P., Laury, R., McNeely, B. W., and Smith, L. A., U.S. Govt. Print. Office, Washington, DC, USA, 475-611, https://doi.org/10.2973/dsdp.proc.10.119.1973, 1973.

Sanfilippo, A. and Riedel, W. R.: Revision of the radiolarian genera Theocotyle, Theocotylissa and Thyrsocyrtis, Micropaleontology, 28, 170-188, https://doi.org/10.2307/1485229, 1982.

Sanfilippo, A. and Riedel, W. R.: The origin and evolution of Pterocorythidae (Radiolaria); a Cenozoic phylogenetic study, Micropaleontology, 38, 1-36, https://doi.org/10.2307/1485841, 1992.

Sanfilippo, A., Westberg-Smith, M. J., and Riedel, W. R.: Cenozoic Radiolaria, in: Plankton Stratigraphy, edited by: Bolli, H. M., Saunders, J. B., and Perch-Nielsen, K., Cambridge University Press, Cambridge, UK, 631-712, 1985.

Shilov, V. V.: Eocene-Oligocene Radiolarians from Leg 145, North Pacific, in: Proceedings of the Ocean Drilling Program, Scientific Results, 145, Rea, D. K., Basov, I. A., Scholl, D. W., and Allan, J. F., Ocean Drill. Program, College Station, TX, USA, 117-132, https://doi.org/10.2973/odp.proc.sr.145.110.1995, 1995.

Shipboard Scientific Party: Site 1260, in: Proceedings of the Ocean Drilling Program, Initial Reports, 207, edited by: Erbacher, J., Mosher, D. C., Malone, M. J., Berti, D., Bice, K. L., Bostock, H., Brumsack, H.-J., Danelian, T., Forster, A., Glatz, C., Heidersdorf, F., Henderiks, T., Janecek, T. R., Junium, C., Le Callonnec, L., MacLeod, K., Meyers, P. A., Mutterlose, H. J., Nishi, H., Norris, R. D., Ogg, J. G., O’Regan, A. M., Rea, B., Sexton, P., Sturt, H., Suganuma, Y., Thurow, J. W., Wilson, P. A., and Wise Jr., S. W., Ocean Drill. Program, College Station, TX, USA, 1-113, https://doi.org/10.2973/odp.proc.ir.207.107.2004, 2004.

Souza, A. L., Eilert, V. M. P., de Souza Lima Fidalgo, T., and Mendonça Filho, J. G.: Early to middle Eocene radiolarian biostratigraphy for the mid-latitude South Atlantic Ocean, Site 356, DSDP LEG 39, Mar. Micropaleontol., 136, 66-89, https://doi.org/10.1016/j.marmicro.2017.09.004, 2017.

Souza, A. L., Eilert, V. M. P., Souza Lima Fidalgo, T., dos Reis, I. P., Vilela, C. G., and Mendonça Filho, J. G.: Late middle Eocene to early Oligocene radiolarian bios- 
tratigraphy in the Southern Ocean (Agulhas Ridge, ODP Leg 117, Site 1090), Mar. Micropaleontol., 169, 102038, https://doi.org/10.1016/j.marmicro.2021.102038, 2021.

Speijer, R. P., Pälike, H., Hollis, C. J., Hooker, J. J., and Ogg, J. G.: The Paleogene Period, in: Geologic time scale 2020, Chapter 28, edited by: Gradstein, F. M., Ogg, J. G., Schmitz, M. D., and Ogg, G. M., Elsevier, Amsterdam, the Netherlands, 1087-1140, 2020.

Spencer-Cervato, C., Lazarus, D. B., Beckmann, J. P., von Salis Perch-Nielsen, K., and Biolzi, M.: New calibration of Neogene radiolarian events in the North Pacific, Mar. Micropaleontol., 21, 261-293, https://doi.org/10.1016/0377-8398(93)90023-Q, 1993.

Spencer-Cervato, C., Thierstein, H. R., Lazarus, D. B., and Beckmann, J. P.: How synchronous are Neogene marine plankton events?, Paleoceanography, 9, 739-763, https://doi.org/10.1029/94PA01456, 1994.

Suganuma, Y. and Ogg, J. G.: Campanian through Eocene magnetostratigraphy of sites 1257-1261, ODP leg 207, Demerara rise (Western Equatorial Atlantic), in: Proceedings of the Ocean Drilling Program, Scientific Results, 207, edited by: Mosher, D. C., Erbacher, J., and Malone, M. J., Ocean Drill. Program, College Station, TX, USA, 1-48, https://doi.org/10.2973/odp.proc.sr.207.102.2006, 2006.

Suzuki, N., Ogane, K., and Chiba, K.: Middle to Late Eocene polycystine radiolarians from the Site 1172, Leg 189, Southwest Pacific, News of Osaka Micropaleontologists (NOM), Special Volume 14, 239-296, 2009.

Suzuki, N., O'Dogherty, L., Caulet, J.-P., and Dumitrică, P.: A new integrated morpho- and molecular systematic classification of Cenozoic radiolarians (Class Polycystinea) - suprageneric taxonomy and logical nomenclatorial acts, Geodiversitas, 43, 405573, https://doi.org/10.5252/geodiversitas2021v43a15, 2021.

Takemura, A.: Radiolarian Paleogene biostratigraphy in the southern Indian Ocean, Leg 120, in: Proceedings of the Ocean Drilling Program, Scientific Results, 120, edited by: Schlich, R., Wise Jr., S. W., Palmer Julson, A. A., Aubry, M.-P., Berggren, W. A., Bitschene, P. R., Blackburn, N. A., Breza, J., Coffin, M. F., Harwood, D. M., Heider, F., Holmes, M. A., Howard, W. R., Inokuchi, H., Kelts, K., Lazarus, D. B., Mackensen, A., Muruyama, T., Munschy, M., Pratson, E., Quilty, P. G., Rack, F., Salters, V. J. M., Sevigny, J. H., Storey, M., Takemura, A., Watkins, D. K., Whitechurch, H., and Zachos, J., Ocean Drill. Program, College Station, Texas, USA, 735-756, https://doi.org/10.2973/odp.proc.sr.120.177.1992, 1992.
Wade, B. S., Pearson, P. N., Berggren, W. A., and Pälike, H.: Review and revision of Cenozoic tropical planktonic foraminiferal biostratigraphy and calibration to the geomagnetic polarity and astronomical time scale, Earth-Sci. Rev., 104, 111-142, https://doi.org/10.1016/j.earscirev.2010.09.003, 2011.

Westerhold, T. and Röhl, U.: Orbital pacing of Eocene climate during the Middle Eocene Climate Optimum and the chron C19r event: Missing link found in the tropical western Atlantic, Geochem. Geophy. Geosy., 14, 4811-4825, https://doi.org/10.1002/ggge.20293, 2013.

Westerhold, T., Röhl, U., and Laskar, J.: Time scale controversy: Accurate orbital calibration of the early Paleogene, Geochem. Geophy. Geosy, 13, Q06015, https://doi.org/10.1029/2012gc004096, 2012.

Westerhold, T., Röhl, U., Pälike, H., Wilkens, R., Wilson, P. A., and Acton, G.: Orbitally tuned timescale and astronomical forcing in the middle Eocene to early Oligocene, Clim. Past, 10, 955-973, https://doi.org/10.5194/cp-10-955-2014, 2014.

Westerhold, T., Röhl, U., Frederichs, T., Bohaty, S. M., and Zachos, J. C.: Astronomical calibration of the geological timescale: closing the middle Eocene gap, Clim. Past, 11, 1181-1195, https://doi.org/10.5194/cp-11-1181-2015, 2015.

Weaver, F. M. and Dinkelman, M. G.: Cenozoic radiolarians from the Blake Plateau and the Blake-Bahama Basin, DSDP Leg 44, in: Initial Reports of the Deep Sea Drilling Project, 44, edited by: Benson, W. E., Sheridan, R. E., Pastouret, L., Enos, P., Freeman, T., Murdmaa, I. O., Worstell, P., Gradstein, F., Schmidt, R. R., Weaver, F. M., and Stuermer, D. H., U.S. Govt. Print. Office, Washington, DC, USA, 865-886, https://doi.org/10.2973/dsdp.proc.44.138.1978, 1978.

Witkowski, J., Bohaty, S. M., McCartney, K., and Harwood, D. M.: Enhanced siliceous plankton productivity in response to middle Eocene warming at Southern Ocean ODP Sites 748 and 749, Palaeogeogr. Palaeoclimatol. Palaeoecol., 326-328, 78-94, https://doi.org/10.1016/j.palaeo.2012.02.006, 2012. 